Article

\title{
Covenant of Mayors: Local Energy Generation, Methodology, Policies and Good Practice Examples
}

\author{
Albana Kona ${ }^{1, *}$, Paolo Bertoldi ${ }^{1}$ and Şiir Kılkışs ${ }^{2}$ \\ 1 European Commission, Joint Research Centre (JRC), 21027 Ispra, Italy; paolo.bertoldi@ec.europa.eu \\ 2 The Scientific and Technological Research Council of Turkey (TÜBİTAK), Ankara 06100, Turkey; \\ siir.kilkis@tubitak.gov.tr \\ * Correspondence: albana.kona@ec.europa.eu
}

Received: 30 December 2018; Accepted: 3 March 2019; Published: 13 March 2019

\begin{abstract}
Local authorities and cities are at the forefront of driving the energy transition, which plays a crucial role in mitigating the effects of climate change. The greenhouse gas emissions in cities, due to energy consumption, are placed into two categories: direct emissions generated from the combustion of fossil fuels mainly in buildings and transport sectors, and indirect emissions from grid-supplied energy, such as electricity and district heating and/or cooling. While there is extensive literature focused on direct greenhouse gas emissions accounting in cities' inventories, research has focused to a lesser extent on allocation methods of indirect emissions from grid-supplied energy. The present paper provides an updated definition for the concept of local energy generation within the Covenant of Mayors initiative and proposes a new methodology for indirect emission accounting in cities' greenhouse gas emission inventories. In addition, a broader policy framework in which local action is taken is discussed based on the European Union energy and climate policies, and over 80 exemplary Covenant of Mayors good practices are identified across the technology areas of local energy generation and four modes of urban climate governance. The contributions of the paper demonstrate that local authorities have the capacity to support and mobilize action for local energy generation investments through the multiple modes of urban climate governance to update and strengthen climate action
\end{abstract}

Keywords: Covenant of Mayors; indirect emission allocation; local energy generation

\section{Introduction}

An increasing number of cities and local governments adhere to transnational initiatives that are active on climate change mitigation. Cities that adhere to transnational networks on climate change by making emission inventories and climate action plans publicly available, although in the absence of obligation, render themselves accountable both globally as well as locally [1]. Their performance and identity are increasingly scrutinized in terms of global impact and exploited in the scientific literature [2]. This includes factors influencing the cities' participation in the networks and multilevel governance models that include observed [3-12] drivers influencing the emissions and target setting [13-16], tools and strategies for the redaction of the climate action plans [17-22] and benchmarking methods [23-26]. The factors further involve the assessments of the global contribution of local climate mitigation actions [27-34].

In the European Union (EU), local authorities (LA) and cities have a crucial role in building public support for the EU's energy and climate goals, while deploying more decentralized and integrated energy systems. The Covenant of Mayors (CoM) is an EU based initiative, which started in 2008. The CoM has been a disrupting phenomenon in the arena of transnational initiatives, which have expanded tremendously over the past 10 years [35], covering more than 7,850 local authorities and 
252 million inhabitants as of December 2018. The CoM at the time of writing the paper is part of the Global Covenant of Mayors initiative, while this paper specifically addresses the experience gathered in the CoM in Europe between 2008 and 2018.

When LAs join the initiative, the CoM signatories (all of whom participate voluntarily) commit to reduce the levels of carbon dioxide $\left(\mathrm{CO}_{2}\right)$ emissions in their territories by at least $20 \%$ by 2020 or at least $40 \%$ by 2030 through the implementation of a Sustainable Energy Action Plan (SEAP). Recently, actions on adaptation (climate risk assessment) have also been included in addition to those on mitigation. The combined plans are called Sustainable Energy and Climate Action Plans (SECAPs). In this paper, the focus is on climate mitigation action plans with commitment targets for 2020, i.e., the SEAPs. The CoM is a unique feature of multilevel polycentric governance that goes far beyond transnational city networking [11]. The initiative is supported by the European Commission and managed jointly by the Covenant of Mayors' Office (CoMO), a consortium of cities' networks and the Commission's Joint Research Centre (JRC), which provides scientific and methodological support. The latest overall assessment of the initiative by JRC [36] shows that the signatories' overall commitment to reducing greenhouse gas (GHG) emissions is $27 \%$ by 2020 , i.e., 7 percentage points above the minimum requested target of $20 \%$. Based on data from 315 implementation reports accompanied by a monitoring emissions inventory (MEI) (covering 25.5 million inhabitants and mainly for the period 2012-2014), a 23\% overall reduction in emissions is observed to be already achieved.

The CoM reporting framework requires a three-step approach to the signatories: i) submission of emission inventories according to their standards, ii) setting a mitigation target as well as drawing a climate action plan, and lastly, iii) monitoring the progress towards the targets. The minimum requirement includes all the direct emissions that are produced within geographical boundaries (buildings and urban transport sectors), as well as indirect emissions associated with the final consumption of grid electricity and of heating/cooling networks. The local generation of energy and associated direct emissions are not part of the activity sectors that are included in the emission inventory but are considered in the calculation of the local emission factors to be applied to the consumption of grid supplied energy [37].

While accounting of direct emissions sources generally follows a coherent approach to those of the Intergovernmental Panel on Climate Change (IPCC), indirect emissions accounting is more complex and challenging as it requires methods on assessing the average emission factor of grid supplied energy. Grid supplied energy can take the form of electricity and district heating/cooling carriers. The identification of the emission sources of heat/cold production could be straightforward due to the limited number of generation units fueling the networks and certainly because heat can be transported effectively only for short distances from generation units to the users, compared to electricity. Therefore, in defining the criteria for the classification of local energy generation units, the focus herein is only on electricity, and the CoM methodology regarding accounting for the indirect emissions associated with grid supplied energy consumptions in cities is introduced.

Further within the method, a broader policy framework in which local action is taken is discussed based on the EU energy and climate policies. Over 80 exemplary good practices are overviewed across the technology areas of local energy generation ranging from photovoltaics, solar thermal, wind energy, hydroelectric power, bioenergy, geothermal energy, combined heat and power (CHP), district heating and/or cooling (DH/C) and smart grids, as well as energy generation from waste and wastewater based on the CoM Signatories' good practices. These good practices are associated with the urban climate governance options that have been put into action by the CoM signatories. Overall, the paper addresses multiple gaps in the literature by updating the approach for indirect emissions accounting and the linkage of good practices in the CoM Signatories' good practices database to the four modes of urban climate governance. 


\section{Materials and Methods}

The methods are presented in the subsequent sections based on the definition of local energy generation, followed by the accounting of the indirect emissions in the CoM framework. The technical metrics that are important for an accurate and realistic accounting of indirect GHG emissions are further supported with the identification of good practices that are necessary to increase local energy generation. In this context, the method of the research work is summarized in Figure 1 with the aim of allowing authorities at the local level the opportunity to update and strengthen climate action. The broader policy framework in which local action is taken is also discussed based on EU energy and climate policies, the effective interaction of which is necessary for policy alignment.

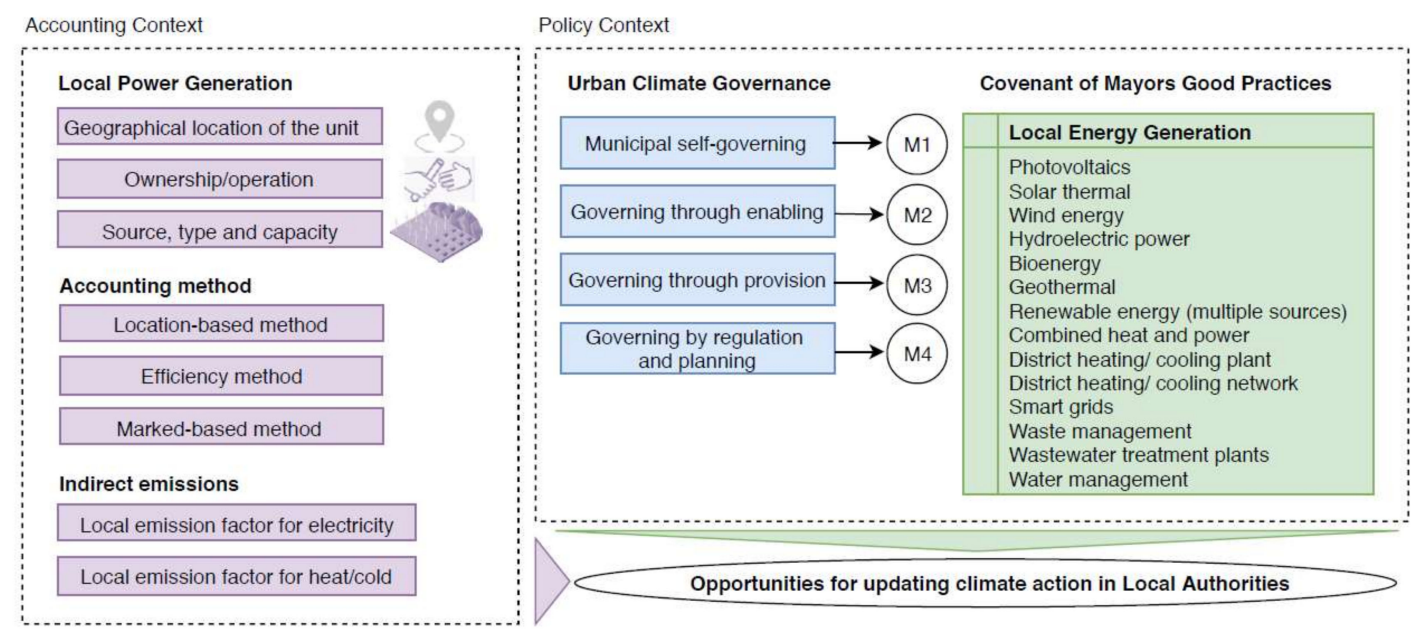

Figure 1. Overview of the accounting context and the policy context for local energy generation. Source: own elaboration.

\subsection{Covenant of Mayors Definition of Local Power Generation}

The grid-supplied electricity is produced by a plurality of generation sources, ranging from distributed to centralized power plants, which can be located inside or outside the geographical boundaries of the cities' emission inventory.

Distributed generation is generally defined in the literature as electric power generation connected to the electrical distribution networks or on the customer side of the network, while usually, the connection of generation units to the transmission network is typical of centralised generation. The central idea of distributed generation, however, is to locate generation close to the load, hence on the distribution network or on the customer side of the meter. The distributed power facilities may differ according to "the purpose, the power scale, the power delivery, the technology, the environmental impact, the mode of operation, and the penetration of distributed generation" [38-41].

Based on the above definitions, a number of questions arise: what is local generation and how can it be differentiated from the national ones? Can it be assimilated into the definition of distributed generation? Generally, the term "distributed generation" refers to renewable energy technologies and it is often interchangeable with the term "local generation".

In relation to GHG emissions accounting, the present paper deals with the concept of local energy generation, which differs mainly from distributed generation. Within the CoM initiative that deals mainly with climate change actions at the local level, the environmental impact of power generation is of high importance, as well as the capability of the local governments to properly address it in their climate action plans. The regional context also affects the criteria, taking into account the national framework of energy and climate governance, characterized by different jurisdictions between state and non-state actors. Hence, there is a need to clearly define the criteria on which a power generation 
facility can be classified as local generation, and therefore to be accounted in the cities' emission inventories within the CoM framework.

The following main aspects were identified to be discussed in defining local production of electricity (LPE) within the scope of the CoM framework, and more precisely the location, the ownership, the source, the type of the technology and the capacity or power scale of the local generation facilities.

- Geographical location of the unit: The location of the energy unit in the local territory is the first criterion. The geographical boundaries of the "local territory" are the administrative ones of the entity (municipality, region) governed by the local authority, which is a signatory to the CoM. Hence, electricity that is produced by installations/plants located inside the local territory has to be included in assessment of the LPE.

- Ownership/operation: All plants/installations under the direct control of the LA (operated and/or at least partly owned by the municipality) should be accounted for in the calculation of the LPE. Therefore, electricity produced by installations/plants located outside the local territory can also be optionally included if they are under the direct control of the LA. The amount of the electricity production can be assessed according to the responsibility of the LA and the share of ownership of all partners (municipalities or commercial partners), which avoids double counting inside and outside the territory. The motivation for taking into account generation facilities under municipality control is that the LA should lead by example on climate actions starting from their own/operated facilities.

- $\quad$ Source, type and capacity of the local electricity production unit: The method described in this paper recommends including all the individual electricity generation units in the local territory and also any plant outside the local territory that is owned and/or operated by LA, classified by the type and capacity as below:

- Local electricity production from renewable sources and combustible renewables are classified regardless of the technology and capacity, with the exclusion of the electricity sold to third parties that are located outside the local administrative boundaries and are identified through disclosed attributes. The rationale behind this is similar to the concept of the "residual mix" used by member states (MS) in the EU for assessing the grid emission factor. When determining the residual mix, MS often exclude the cancellation of electricity attributes (purchased via a Guarantee of Origin (GO) certificate in Europe) from the grid emission average [42]. The GOs are tracking instruments, introduced in 2009 by the Renewable Energy Directive (RED 2009/28/EC), that provide a means of demonstrating the origin of renewable electricity to consumers. The GOs system is a virtual one where the renewable attribute of energy trades separately from the physical energy. The usage is limited within 12 months of production of the corresponding energy unit, and is cancelled once it has been used.

- Local electricity production from non-renewable sources, classified by types and capacity:

- $\quad$ All combined heat and power plants, without capacity limit: the CHP system can be defined as local generation, as the second product (thermal energy) is consumed locally. Combined cycle gas turbines, internal combustion engines, combustion turbines, biomass gasification, geothermal, and Stirling engines, as well as fuel cells, are suitable for CHP processes. The heat demand usually drives the operation process, unless a back-up system for the heat production is in place.

- $\quad$ Electricity-only with a capacity limit of $20 \mathrm{MW}$ of thermal input: According to the principles that are laid out in the CoM, the inventory is not meant to be an exhaustive inventory of all emission sources in the territory but focuses on the energy consumption side and on the sectors and activities (buildings and transport) upon which the local authority has a potential influence. Large industrial power plants, 
covered by cap and trade schemes, such as the European Union Emission Trading Scheme (EU ETS), are not under LAs competence, but regulated by the ETS directive (2003/87/EC).

The amount of electricity to be reported in emission inventories as local electricity production will have a direct influence on the value of the local emission factor for electricity, and consequently, on the emissions that are associated with the consumption of electricity.

\subsection{Covenant of Mayors Methodology on Accounting the Indirect Emissions}

Two methods exist in the literature to allocate the emissions generated via electricity production to the final energy consumer of a given grid: location-based and market-based [43]. The location-based method is grounded on average generation emission factors for defined territories, considering local, subnational, or national boundaries, therefore reflecting the average emission intensity of the grid. In the marked-based method, the emission factors are derived from electricity purchases bundled with contractual instruments. The market-based method presents a higher degree of accuracy in the assessment of the emission factor. However, data collection in the context of market-based methods remains the main challenge when compared to location-based approaches, where local governments need to focus on assessing the indirect emissions of a multitude of consumers in their territories.

In order to calculate the indirect $\mathrm{CO}_{2}$ emissions that are to be attributed to the local consumption of electricity, JRC developed a specific methodology as described in this paper by estimating the local emission factor for electricity (EFE), taking into account both location- and market-based methods, but also an efficiency method for emission allocations in the case of CHPs.

\subsubsection{The Location-Based Method}

The location-based method is used for assessing the amount of electricity and the associated GHG emissions excluding the electricity attributes (i.e., purchased via GOs certificates in Europe). This amount of electricity is associated with the physical electricity that is consumed in the local territory coming from the national energy mix and the local generation units and associated emission factors as below:

- National or European emission factor for electricity consumption (NEEFE): These emission factors can be derived either from international databases, such as the International Energy Agency (IEA) [44], the IPCC emissions factor database [45], or provided by national agencies of MS in the EU (e.g., Italy [46]). The European Commission Joint Research Centre (EC JRC), in the framework of the CoM initiative, also provides regular updates of the NEEFE [47].

- The local energy generation emission factor can be derived directly or is assessable from the local (private or public) electricity provider, costumer and/or unit operator. In case of CHPs, a method has been developed to allocate the emissions based on the energy inputs required to produce separately (not in cogeneration) the same amount of outputs of heat and electricity (as in the CHP power plant output), which is named an efficiency method in the case of CHPs.

\subsubsection{The Efficiency Method in Case of CHPs}

Within the CoM reporting framework, the "efficiency" method for allocating $\mathrm{CO}_{2}$ emissions is the recommended method for LAs to be used in case of CHP power plants located within the geographical boundaries of the territory. The rationale behind this choice is to have a consistent method for emissions accounting with the method recommended in the European Energy Efficiency Directive (EED) $(2012 / 27 / E U)$ for determining the efficiency of the cogeneration process and primary energy savings. This method, called the "efficiency method", uses a reference system to allocate the output. 
In a first step, the ratio of primary energy savings (PES) in comparison to a reference system is calculated. The methodology used to calculate the PES corresponds to the method defined in Annex II of the EED directive. According to Annex II of the EED directive, PES is defined as follows (Equation (1)):

$$
P E S=\left(1-\frac{1}{\frac{\eta_{C H P, h e a t}}{\eta_{\text {REF,heat }}}+\frac{\eta_{C H P, e l}}{\eta_{\text {REF,el }}}}\right)
$$

where:

- $\quad \eta_{R E F, e l}$ is the efficiency reference value for separate electricity production at national level;

- $\eta_{R E F, h e a t}$ is the efficiency reference value for separate heat production;

- $\quad \eta_{C H P, e l}$ is the efficiency of electricity production with the CHP power plant, measured as a ratio between the annual amount of electricity produced in output $\left(P_{C H P, e l}\right)$ and the total annual amount of primary energy in input to the CHP power plant $\left(P_{C H P, T O T}\right): \eta_{C H P, e l}=\frac{P_{C H P, e l}}{P_{C H P, T O T}}$;

- $\quad \eta_{C H P \text {, heat }}$ is the efficiency of heat production with the CHP power plant, measured as a ratio between the annual amount of heat produced in output $\left(P_{C H P, \text { heat }}\right)$ and the total annual amount of primary energy in input to the CHP power plant $\left(\mathrm{P}_{\mathrm{CHP}, \mathrm{TOT}}\right): \eta_{C H P, \text { heat }}=\frac{P_{\mathrm{CHP} \text {, heat }}}{P_{\mathrm{CHP}, \mathrm{TOT}}}$.

In a second step, the share of primary energy attributed to each of the two outputs electricity and heat can be calculated as follows. Regarding the share of allocation to heat, this amounts to a re-arrangement of Equation (1) based on the term (1 - PES) multiplied by the ratio of primary energy used for heat production in a reference scenario $\left(\frac{P_{C H P, \text { heat }}}{\eta_{\text {REF,heat }}}\right)$ on the primary energy used in the cogeneration scenario to produce the same amount of heat $\left(\mathrm{P}_{\text {CHP,TOT }}\right)$, as $\left(\frac{P_{\text {CHP, heat }}}{\eta_{\text {REF heat }} \times P_{\text {CHP,TOT }}}\right)$.

Therefore, the ratio of primary energy allocated to heat is obtained using Equation (2):

$$
\text { ratio allocated to heat }=(1-P E S) \times\left(\frac{P_{C H P, \text { heat }}}{\eta_{R E F, \text { heat }} \times P_{C H P, T O T}}\right)=\frac{\frac{P_{C H P, \text { heat }}}{\eta_{R E F, \text { heat }}}}{\left(\frac{P_{C H P, \text { heat }}}{\eta_{R E F, \text { heat }}}+\frac{P_{C H P, e l}}{\eta_{R E F, e l}}\right)}
$$

This method allocates the emissions based on the energy inputs required to produce separately (not in cogeneration) the same amount of outputs of heat and electricity (as in the CHP power plant output) as follows:

$$
\begin{aligned}
& \mathrm{CO}_{2} \text { emissions allocated to heat }=\mathrm{CO}_{2 \mathrm{CHP}, \text { heat }}=\frac{\frac{P_{\mathrm{CHP}, \text { heat }}}{\eta_{R E F, \text { heat }}}}{\left(\frac{P_{\mathrm{CHP}, \text { heat }}}{\eta_{R E \text {,heat }}}+\frac{P_{\mathrm{CH}, \text { el }}}{\eta_{R E F, e l}}\right)} \times \mathrm{CO}_{2 \mathrm{CHP}, \mathrm{TOT}} \\
& \mathrm{CO}_{2} \text { emissions allocated to electricity }=\mathrm{CO}_{2 \mathrm{CHP}, \text { el }}=\mathrm{CO}_{2 \mathrm{CHP}, \mathrm{TOT}}-\mathrm{CO}_{2 \mathrm{CHP}, \text { heat }}
\end{aligned}
$$

where:

- $\mathrm{CO}_{2 \mathrm{CHP}, \mathrm{TOT}}$ is the total amount of $\mathrm{CO}_{2}$ emissions in the $\mathrm{CHP}$ power plant $\left(\mathrm{tCO}_{2}\right)$;

- $\mathrm{CO}_{2 \mathrm{CHP} \text {, heat }}$ is the total amount of $\mathrm{CO}_{2}$ emissions allocated to heat production $\left(\mathrm{tCO}_{2}\right)$;

- $\mathrm{CO}_{2 \mathrm{CHP}, e l}$ is the total amount of $\mathrm{CO}_{2}$ emissions allocated to electricity production $\left(\mathrm{tCO}_{2}\right)$;

- The recommended value in the CoM of the typical efficiency of separate electricity production $\left(\eta_{R E F, e l}\right)$ to be used is set in the national efficiency factor for electricity generation and/or the average of EU regularly published by Eurostat (46\%) in Reference [48];

- The recommended value of the typical efficiency of separate heat production $\left(\eta_{R E F, \text { heat }}\right)$ to be used in the CoM framework is $90 \%$.

\subsubsection{The Market-Based Method}

The market-based method is used for assessing the amount of electricity and GHG emissions that are associated, purchased and sold through energy attributes as certified electricity (CE) [49]. Certified 
electricity is the electricity that meets the criteria for GO of electricity produced from renewable energy sources as set in Article 15 of RED Directive.

- Instead of purchasing the "mixed" electricity from the grid, the local authority/other local actors can decide to purchase certified electricity. The LA will report the amount of purchased electricity $\left(\sum C E_{\text {purchased }}\right)$, which is not already reported under LPE.

- The amount of renewable energy produced by facilities that are located inside the local territory for which the GO of electricity produced from renewable sources is sold to third parties outside the administrative boundaries should not be accounted for as local energy production $\left(\Sigma C E_{\text {sold }}\right)$.

- $\quad \sum C E$ is the certified electricity accounted for in the inventory as given by Equation (5):

$$
\sum C E=\sum C E_{\text {purchased }}-\sum C E_{\text {sold }}
$$

\subsubsection{Indirect Emissions due to Local Electricity Consumption}

Based on the considerations and assumptions presented, the EFE at the local level should be calculated as follows:

- In the case where the local authority would not be a net exporter of electricity (TCE $\geq$ LPE + $\mathrm{CE}$ ), the average emission factor will be equal to the total amount of emissions from electricity consumption assessed with (location-based + market-based instruments) over the total amount of electricity consumption as provided in Equation (6):

$$
E F E=\frac{\left[\left(T C E-\sum L P E-\sum C E\right) * N E E F E+\sum C O_{2 L P E}+\sum C O_{2 C E}\right.}{T C E}
$$

- In the case where the local authority would be a net exporter of electricity (TCE < LPE + CE), Equation (7) will apply:

$$
E F E=\frac{\sum C O_{2 L P E}+\sum C O_{2 C E}}{\sum L P E+\sum C E}
$$

where:

- $\quad E F E$ is the local emission factor for electricity consumption $\left(\frac{\mathrm{tCO}_{2}}{M W h}\right)$

- $\quad T C E=$ total electricity consumption (MWh) in the local territory

- $\quad \sum L P E=$ local electricity production from RES and non-RES facilities (MWh)

- $\quad \sum C E=$ certified electricity accounted in the inventory

- $\quad$ NEEFE = national or European emission factor for electricity consumption $\left(\frac{\mathrm{t} \mathrm{CO}_{2}}{M W h}\right)$

- $\quad \sum \mathrm{CO}_{2 L P E}=\mathrm{CO}_{2}$ emissions due to local energy production $\left(\mathrm{tCO}_{2}\right)$

- $\quad \sum \mathrm{CO}_{2 \mathrm{CE}}=\mathrm{CO}_{2}$ emissions $\left(\mathrm{tCO}_{2}\right)$ due the purchase/sold of $\mathrm{CE}$ certified electricity

\subsubsection{Indirect Emissions from Local District Heating and Cooling Consumption}

Indirect emissions from the consumption of heat/cold are estimated based on the emissions that are occurring due to the production of locally consumed heat/cold. If a part of the heat/cold that is produced in the local territory is exported, then the corresponding share of $\mathrm{CO}_{2}$ emissions should be deducted when calculating the emission factor for heat/cold (EFH). In a similar manner, if heat/cold is imported to the local territory from a plant that is situated outside the local territory, then the share of $\mathrm{CO}_{2}$ emissions from this plant that corresponds to the heat/cold consumed in the local territory should be accounted for when calculating the emission factor for heat/cold.

In principle, the total amount of heat/cold produced is different than the quantity of heat/cold that is consumed locally. Differences may occur due to auto-consumption of heat/cold by the utility producing it and or due to the transport and distribution losses of heat/cold. 
The following formula (Equation (8)) should be applied to calculate the $\mathrm{CO}_{2}$ emission factor for heat/cold (EFH), taking the above-mentioned issues into consideration:

$$
E F E=\frac{\sum \mathrm{CO}_{2 L P H}+\sum \mathrm{CO}_{2 I H}-\sum \mathrm{CO}_{2 E H}}{\sum L H C}
$$

where:

- $\quad E F H$ is emission factor for heat/cold $\left(\mathrm{tCO}_{2} / \mathrm{MWh}\right.$ or $\mathrm{tCO}_{2}$-eq/MWh)

- $\quad \sum \mathrm{CO}_{2} \mathrm{LPH}$ is total $\mathrm{CO}_{2}$ emissions $\left(\mathrm{tCO}_{2}\right.$ or $\mathrm{tCO}_{2}$-eq) due to the local production of heat/cold

- $\quad \sum \mathrm{CO}_{2 I \mathrm{H}}$ is $\mathrm{CO}_{2}$ emissions related to any imported heat/cold from outside the local territory $\left(\mathrm{tCO}_{2}\right.$ or $\mathrm{tCO}_{2}$-eq)

- $\quad \sum \mathrm{CO}_{2 E H}$ is $\mathrm{CO}_{2}$ emissions related to any heat/cold that is exported outside of the local territory $\left(\mathrm{tCO}_{2}\right.$ or $\mathrm{tCO}_{2}$-eq)

- $\quad$ LLHC is local heat/cold consumption (MWh)

In the case of CHP plants, it is first required to distinguish between the emissions due to heat and electricity production. District cooling, i.e., purchased chilled water, is in principle a similar product as purchased district heating. However, the process to produce district cooling is different from the process to produce district heating, and there is a larger variety of production methods. If local production of district cooling occurs, or if district cooling is consumed as a commodity by end-users, then the local authority is recommended to contact the district cooling provider for information on the use of fuels or electricity to provide cooling. Accordingly, the emission factors for fuels and electricity presented in this paper can be applied. The approach as put forth in this paper is essential for enabling LAs to account for indirect emissions accurately and realistically.

\section{EU Energy and Climate Policies}

EU energy and climate policies have large influences on the transition to sustainable local energy systems. In the following, a brief description of the main updated EU energy and climate policies as a total governance system, which strongly influences the municipal policies for climate actions, is reported.

A first major milestone of climate change in the EU policy was the launch of the EU emission trading scheme (ETS) $(2003 / 87 / E C)$ in 2005, establishing a scheme for greenhouse gas emission allowance trading within the EU. According to the ETS directive and subsequent amendments, all combustion installations above $20 \mathrm{MW}$ of thermal input should be part of the scheme with the exception of installations exclusively using biomass, installations for the incineration of hazardous or municipal waste and installations used for research, development and testing of new products. Some installations are also temporary or conditionally excluded from ETS, such as hospitals and some installations below $35 \mathrm{MW}$. Having an EU established scheme for regulating the emissions of such large combustion installations means the jurisdiction of the LAs is limited. Therefore, the emissions from the ETS installations are not recommended to be accounted in the LAs emission inventories, unless the local government is somehow involved through ownership or operation, or the installation is a CHP power plant.

A second milestone relates to the "A Clean Energy for all Europeans" package, launched in November 2016. By the end of December 2018, a political agreement for the adoption of this package has been reached, formulating three key energy and climate targets by 2030: (1) to reduce greenhouse gas emissions further by at least $40 \%$ by 2030 as compared with 1990, (2) a binding renewable target of $32 \%$ and (3) an energy efficiency target of $32.5 \%$. The important role of the Covenant is mentioned and acknowledged in the package as a collaborative platform that allows local authorities to learn from one another, as also highlighted in literature [12,23-26]. The package is introduced and is updating a set of legislations including the new Governance Regulation of the Energy Union, the revised Renewable Energy Directive, the revised Energy Efficiency Directive, the revised Energy Performance in Buildings 
Directive and the revised Electricity Directive and Regulation. The main aspects of these updated EU policies to supporting local energy policies are analyzed in the following:

- The new regulation on governance of the energy union and climate action is based on integrated national energy and climate plans (NECPs), covering 2021-2030 and all the five dimensions of the Energy Union (i.e., decarbonisation, energy efficiency, energy security, internal energy market and research, innovation and competitiveness). The Governance Regulation establishes a clear and transparent regulatory framework, ensuring that the objectives of the EU's 2030 energy and climate targets are achieved. Similarly, in the CoM, the governance of integrated energy and climate action plans has been in place for a decade through transparent and robust framework of reporting and monitoring of the so-called sustainable energy and climate action plans in municipalities. Although in the absence of obligation, cities adhere voluntarily to the initiative and they render themselves accountable both globally as well as locally [1]. The largest difference perhaps between national and transnational systems, such as CoM, on the governance is related to possibilities for sanctioning non-compliance with soft measures such as removal of support or suspension from the initiative [35].

- The RED II directive establishes a clear and stable framework for citizens and communities as stakeholders in the energy system, acknowledging their involvement individually, or through renewable energy communities (RECs). RECs are legal entities based on open and voluntary participation, effectively owned and controlled by the members (including citizens, small and medium-sized enterprises (SMEs), local authorities or municipalities), with the primary purpose of providing environmental, economic or social community benefits for its members or for the local areas where it operates, rather than financial profits. Moreover, the revision requires MS to put in place enabling frameworks, and simplify administration procedures to support citizens and communities investing in renewables. The LAs, through their capacity as self-governing and facilitator may participate as members or operators through their own utilities in renewable energy communities, building legitimacy and political endorsements for their climate action plans. The LA, through its capacity as a regulator and enabler, may further facilitate and accelerate the permit-granting procedure for renewable energy projects and/or facilitate the uptake of RECS in new urban development or in large renovation of multi apartment blocks.

- The Energy Efficiency Directive (EED) and its revision (2018/2002/EC), has two articles of the directive that are of particular interest to local authorities:

(I) Article 14 with the overall objective to encourage the identification of cost-effective potential for delivering energy efficiency, principally through the use of cogeneration, efficient district heating and cooling and the recovery of industrial waste heat or, when these are not cost-effective, through other efficient heating and cooling supply options, and the delivery of this potential. An LA, through its capacity as a regulator and enabler, may facilitate and participate in the process of planning cost-effective heating and cooling networks, identifying possible recovery of waste heat in facilities located within the territory.

(II) Article 7 on energy savings obligations: MS, in designing the policy measures to fulfill the obligations to achieving energy savings [50], should take into account the need to alleviate energy poverty through giving priority to financing the implementation of measures among vulnerable households, and where appropriate in social housing. The LAs are key player in this process of identifying and giving priority of implementing energy savings among vulnerable households.

- The Energy Efficiency in Buildings Directive (EPBD) and its revision (2018/844/EC): First and foremost, all new buildings must be nearly zero-energy buildings by 31 December 2020 (public buildings by 31 December 2018) and the low amount of energy that these buildings require have to be supplied mostly from renewable sources. Meanwhile, the 2018 EPBD revision requires MS to establish a long term renovation strategy to fully decarbonize the national building stocks by 2050. As highlighted in this directive, the local authority itself assumes an exemplary role in the implementation of these actions. Committing to highly efficient buildings and adopting renewable sources in their own facilities are ways local authorities can reduce emissions. By developing energy 
efficiency and renewable projects and in their buildings, local authorities set an example to the local community, inspiring citizens to adopt sustainable and low-carbon practice. Moreover, local authorities empowered with the jurisdiction to build upon national policies in the building sector can implement codes and regulation with more stringent requirements than national ones. Through these regulations, integrated actions to improve energy efficiency in the buildings are provided and the use of renewable sources for space heating and cooling is fostered.

In conclusion, the revised EU policy governance on energy and climate and its implementation at the national level calls for an enhanced communication process for boosting the multilevel and polycentric governance of urban climate action plans.

\section{Urban Energy and Climate Governance to Support Sustainable Energy and Climate Action Plans}

The accurate and realistic accounting of indirect emissions by LAs is important within the policy cycle at the local level from planning to taking necessary action. At the same time, policy support from a synthesis of urban climate governance options [51] is required to transform the local energy structure. Governance relates to mechanisms directed toward the coordination of multiple forms of state and non-state action across scales (from local/municipal authorities to national governments), as well as through networks and partnerships that operate within and between cities [12]. The CoM is a unique feature of multilevel polycentric governance that goes far beyond transnational city networking [11]. Such governance has a crucial role in demonstrating, guiding and influencing key measures for achieving emissions reductions through efficient electricity and local heat/cold production. The transition towards a more sustainable urban environment at the local level begins with a common understanding that there is significant potential to curb the city's $\mathrm{CO}_{2}$ emissions. This understanding provides a basis upon which political leadership instigates a process of exploring possibilities and discussing different options with a wide range of stakeholders towards selecting, detailing, implementing and monitoring local action. In this process, LAs have the capacity to support and mobilize action for local energy generation investments through several modes of urban climate governance

In the following, four modes of urban energy and climate governance are investigated that summarize the scope of each mode, along with the main tools and exemplary actions to support local energy sustainability. The modes of urban energy and climate governance, which are based on definitions from Reference [52], can be mainly summarized as:

- $\quad$ municipal self-governing (M1)

- municipal enabling (governing through enabling) (M2)

- $\quad$ governing through provision (M3)

- governing by regulation and planning (authority) (M4).

Overall, the barriers that can be addressed with each main tool under these modes of governance are different. For this reason, it is often necessary to combine multiple modes of governance to reinforce and align incentives for particular objectives. This must be supported by an analysis of the legal, physical, social and economic barriers hindering local energy generation prior to considering corrective actions and measures. In the following, a collection of good practices on local energy generation based on the CoM Signatories' Benchmarks of Excellence and the literature [53] is provided, especially those that are connected to best practices in CoM signatories.

\subsection{Municipal Self-Governing}

Municipal self-governing involves aspects that are related to the management of the LAs estate to increase local energy generation, renewable energy demonstration projects in public facilities and public procurement. Prior to the good practices, these opportunities are put forth below: 
- Management of the LAs estate to increase local energy generation: The LA requires renewable energy generation to provide for a high share of the building energy needs in the design of new public buildings and the retrofit of existing public buildings. Town halls with innovative solar energy façades and schools that are powered by photovoltaic panels may be given as initial examples. When possible, the LA can also require $\mathrm{DH} / \mathrm{C}$ grids in public buildings areas, including through contract to connect municipal buildings to the district heating and/or cooling network.

- Renewable energy demonstration projects in public facilities: Public buildings provide important opportunities as demonstration sites for renewable energy technologies. LAs can publicly test and show the success of renewable energy measures that are implemented in public buildings. Moreover, priority may also be given to less wide-spread technologies, such as low-power absorption chillers and micro-cogeneration to share the results with the stakeholders. The pilot projects can also attract the interest of private stakeholders upon which similar projects can be replicated across the city. Additional opportunities include the use of biogas from wastewater treatment facilities in a CHP or in public vehicles fleet driven by biogas/natural gas.

- Public procurement: Public procurement can be used to prescribe a share of renewable supply in the case of service contracts to public facilities. One of the prerequisites for the use of public procurement as a strategic tool to increase local energy generation in municipality-owned assets is the identification of appropriate public buildings and facilities. Inefficient heating plants and boilers at these sites can be replaced by cogeneration, trigeneration, renewable energy installations or a combination thereof according to the energy demand profile for heating and cooling. Actions at these sites can also have a high replication potential across private sectors, such as the food industry and hotels, among others.

\subsection{Municipal Enabling}

Municipal enabling represents opportunities that provide additional policy support for mobilising actors, such as public-private partnerships as well as awareness-raising and training activities.

- Public-private partnerships: Co-operation between the municipality, local investors and local citizens are deemed to be vital factors of success for realising the transition to $100 \%$ renewable energy systems [54]. The leadership of local governments can play an important role in forging partnerships and pooling resources across the public and private sectors. Examples include public-private partnerships for anaerobic digestion of biowaste for CHP-based district heating and the co-financing of public energy upgrading between local and regional authorities and private investors. Especially in the case of the bioenergy sector, the supply of urban biowaste can depend on citizen awareness and motivation to put aside organic waste for separate collection. For this reason, it is also important to motivate citizens in partaking in waste management strategies to enable the use of organic waste to produce biogas.

- Awareness raising and training activities: Training material, such as those of European projects' [55], include promotional campaigns for solar energy campaigns. Similar campaigns can be effectively combined with supporting tools, including the provision of a solar atlas and solar land registry (Berlin Solar Atlas (Germany), Paris Solar Land Registry (France), Vlaams-Brabant Climate Map (Belgium), etc.)

- Community cooperatives for local energy projects: Community cooperatives for local energy projects can enable citizens to have collective ownership and management of projects, including those based on renewable energy generation. At the same time, community cooperatives require a certain level of citizen engagement and empowerment. For this reason, awareness building activities can be used to mitigate perceptions of risk of renewable energy co-operatives that can hinder the profitability of such initiatives as well as their contribution to energy transition objectives. In this case, awareness building in support of local energy generation can also be used to satisfy needs to empower community participation and buy-in within such initiatives [56]. 


\subsection{Governing through Provision}

Governing through provision encompasses the process of making available direct energy infrastructure investments, as well as incentives and grants for local energy generation.

- Direct energy infrastructure investments: The utilisation of renewable energy sources in the urban built environment may be limited due to insufficiencies in the energy infrastructure. In this case, direct investments at the local level can include those for modernising and expanding DH/C networks. In combination with regulatory means of governance, LAs can further require that connections to the $\mathrm{DH} / \mathrm{C}$ network are compulsory for buildings located in related zones. In the case of municipally owned utilities, minimum quotas for renewable energy sources or co-generation can be set. LAs can also involve utility companies in new projects for local energy generation to take advantage of their experience, facilitate greater access to the grid and reach a larger share of individual consumers. Public housing further provides a venue to promote the integrated use of renewable energy sources, including solar thermal, solar photovoltaic (PV), biomass and micro-cogeneration.

- Incentives and grants for local energy generation: LAs can issue municipal green bonds and create funds for renewable energy deployment. The provision of financial opportunities such as these can overcome market failures and address economic barriers for the widespread deployment of related technologies. In addition, LAs can provide subsidies for connections to the district heating network as well as those that may involve the use of any low temperature heating systems that can reduce the operating temperature of the network to increase its efficiency [57].

- Subsidies for local electricity and thermal energy production based on CHP plants as well as the provision of financing for demonstration projects on smart grids can also accelerate progress towards $\mathrm{CO}_{2}$ mitigation targets based on local energy generation.

\subsection{Governing by Regulation and Planning}

Regarding ordinances on the mandatory use of renewable energy, Solar Thermal Ordinances (STOs) represent one of the most prevalent forms of mandatory regulations for renewable energy. A growing number of European municipalities, regions and countries has adopted such obligations [58]. In addition, municipalities can require mandatory installations of photovoltaic systems among other renewable energy technologies. Regulatory measures can further require households and private companies to purchase green electricity through obligations on local energy suppliers. Other tools for policy action at the local level also include revision of urban planning regulation to consider the necessary infrastructures required for the development of the DH/C.

In addition to setting regulations, strategic energy planning tools and decisions provide a means for local authorities to evaluate and enforce decisions to promote local energy generation. The following steps exemplify instances in which strategic energy planning would be necessary to promote the generation and utilisation of local energy resources, including those of residual heat from the industry, data centres and wastewater treatment plants. Local maps with information on heat demand densities and the locations and magnitudes of residual heat from industry and power generation can largely facilitate this process.

- Evaluation of geothermal energy potential considering legal and technical barriers of ground perforation and the environmental effect on the underground water layer.

- With regard to the use of biomass, making a technical and economical evaluation of the potential of the biomass harvested in public spaces, companies and citizens' properties, the potential impacts of biomass combustion on air quality and health should also be evaluated.

- Considering the integration of residual heat into the district and cooling network, including sources of residual heat from the industry, data centres, wastewater treatment plants and waste incinerators. 
In addition, land use planning should be considered for large-scale solar plants and wind turbines. These aspects call for integrated urban planning processes to support local energy generation decisions as the basis for additional action, such as:

- Establishing an integrated urban planning process to promote renewable energy generation deployment and identifying possible sites to install local energy generation installations, such as those for solar, wind, small hydro and biogas, will ensure the availability and compatibility of public and private space to achieve projects. Some European local authorities offer rooftops of public buildings to private companies for rent to produce energy by means of photovoltaic collectors [59]. Establishing integrated urban planning processes, include those to promote DH/C networks and cogeneration plants, should be supported with mapping tools of thermal energy demand from buildings based on reliable data from utilities.

\section{Key Measures for Transition to Sustainable Local Energy Systems}

The above modes of urban climate governance, which are classified as M1 to M4, need to be used in combination to provide effective policy support. A holistic understanding of the key measures and technological options that are available at the local level is required to support the design and implementation of policies to promote local energy generation. For this reason, key measures are described with the aim of providing guidance towards potential application areas. Insight from signatories that have already undertaken the technological options is summarised to underline the rapid transition that is taking place at the local level based on the promotion of local energy generation with renewable energy.

The EU has the ambition to be the world number one in renewable energy [60]. To fulfil this objective, the next generation of renewable technologies must be developed and the energy that is produced from renewable sources must be integrated into the energy system in an efficient and cost-effective manner. In this context, there is increasing interest in the decentralisation of the energy supply with more local ownership. Local energy supply options can take the form of district energy systems, local power generation utilities and energy services companies (ESCo). LAs can be whole or partial owners of these utilities and promote community partnership. The relevant modes of urban climate governance that are involved showcase the integrated approach that is needed for supporting particular renewable energy solutions, which is also summarized in Figure 2. Examples for the policy measures are based on compilations from the Covenant of Mayors Signatories' Good Practices database [61].

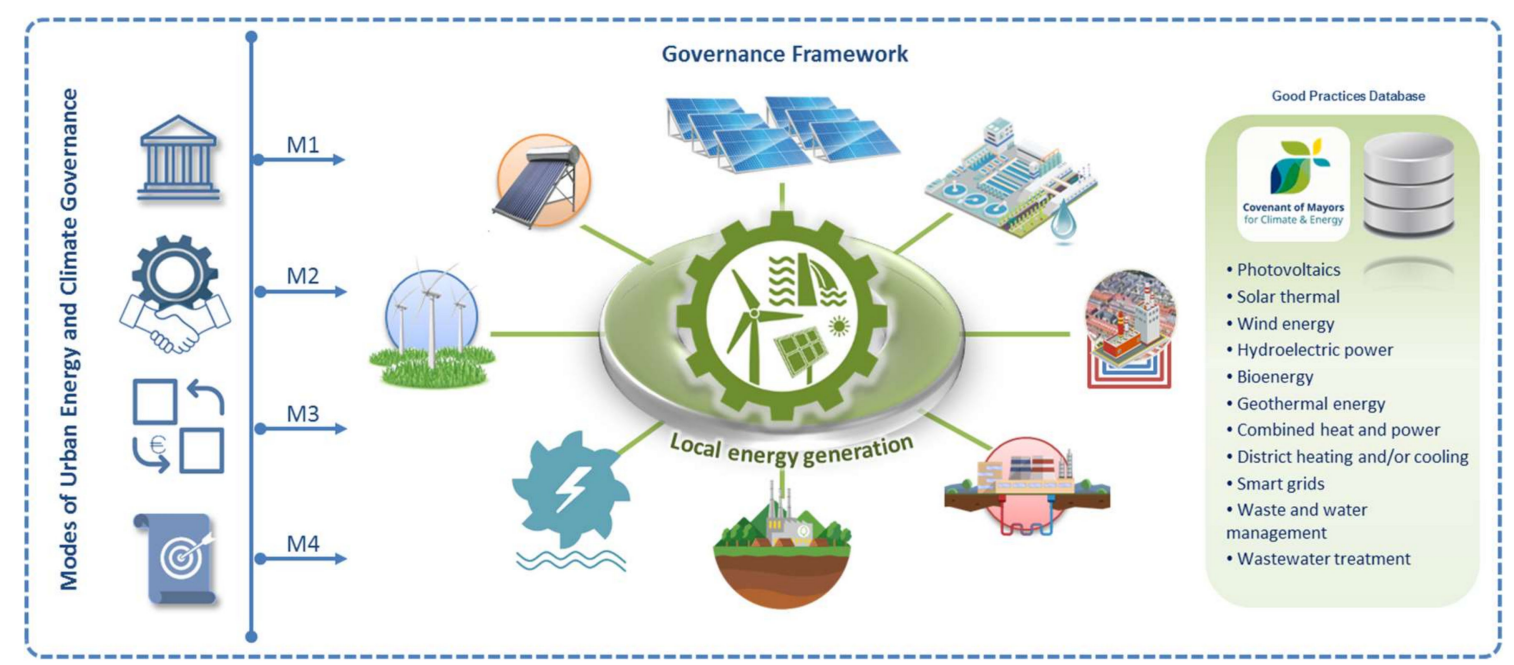

Figure 2. Necessity for a coherent policy mix for local energy generation. Source: own elaboration. 
In particular, Tables A1-A3 in the Appendix A are formed as a representation of the 1059 key actions of CoM signatories in the good practices database [61] as "benchmarks of excellence" for local electricity and local heat/cold production. The good practices were exhaustively scanned and categorised into the renewable energy source and technology areas in Figure 2. The key actions were then combined into 82 representative statements with examples from CoM signatories alongside an identification of the modes of governance M1 to M4 that the key action involves. Based on this overview, it is possible to observe the diversity of governance modes that support renewable energy technologies. Such an overview also extends discussions on modes of governance from the perspective of good practices from CoM signatories with a specific focus on local energy generation.

\subsection{Photovoltaic}

As a widespread measure, CoM signatories are financing and owning photovoltaic (PV) pilot plants on public buildings and facilities based on rooftop PV and building-integrated PV systems (M1). Equally valid measures include installations on the roofs of bus sheds (e.g., $968 \mathrm{~kW}$ in Mantova, Italy, as an action that provides 400 tonnes of $\mathrm{CO}_{2}$ reductions and $990 \mathrm{MWh}$ of local electricity generation [62]), parking lots, and other available areas. Other CoM signatories have constructed a PV park on the ground of a municipal property at a former landfill site, such as in Torrile, Italy, or Évora, Portugal, with about 4000 MWh of local electricity generation based on 3,388 € per tonne $\mathrm{CO}_{2}$ reduced at the time of implementation [63]. The active use of municipal areas for PV technologies also extends to approaches that combine both municipal self-governing (M1) and governing by provision (M3). CoM signatories are giving a concession of surface rights and renting of rooftop areas in public buildings for PV installations and/or promoting PV installations in public buildings based on collaboration with the ESCo and third-party financing for PV systems in school buildings.

As enablers and providers (M2 and M3), CoM signatories are involved in public-private partnerships for photovoltaic solar parks (e.g., 24.2 MW in Coruche, Portugal), as well as city supported photovoltaic campaigns. In Hannover, Germany, the target of the photovoltaic campaign is to reach 1 million square metres of solar modules by 2020 [64]. In the capacity of regulators (M4), LAs are using their authority to put forth energy supplier obligations for PV systems, such as mandates that PV system installations should be equal to a given share of the total installed power in the municipality. In this respect, it is observed that the complete spectrum of governance modes from M1 to M4 is utilised to various extents in ways that promote PV technologies in cities.

Other measures for PV that involve various governance modes as marked in Table A1 include a municipality bonus for PV installation on citizens' roofs, interest-free loans for associations or schools that install PV panel installations (e.g., Bree, Belgium [65]), the provision of PV systems in a civic center that also supplies electric vehicle charging stations ( $135 \mathrm{~kW}$ in Poole, United Kingdom, with a cost of about 3,587 $€$ per tonne $\mathrm{CO}_{2}$ reduction at the time of implementation [66]), and real-time data sharing on electricity generation based on the PV systems of the City Council for purposes of awareness-building (e.g., Málaga, Spain, with 609 MWh of local electricity generation [67]).

In other aspects, awareness-building and planning supporting tools for solar energy are actively promoted based on a solar land registry for roof-top PV (or solar thermal) installations in Paris, France [68], while an online solar chart for identifying preferable areas for solar energy technologies is put into use for the benefit of the local actors in Lisbon, Portugal, with an implementation cost of about 10,000 $€$ [69]. Numerous other CoM signatories are providing online solar roof cadasters for every building in the municipality, e.g., Bremen [70], Fürstenfeldbruck [71] and Hannover [64] in Germany, Barcelona in Spain [72], and others. Important complementary measures include public awareness-building to reach annual increase targets for PV in the private buildings and land use planning for utility-scale PV plants in the municipality within broader aspects of urban planning. 


\subsection{Solar Thermal}

Municipal buildings and facilities can provide a point of acceleration for upscaling solar energy technologies at the urban level, which is also valid for solar thermal technologies. In this capacity (M1), CoM signatories are actively increasing the use of solar collectors on the rooftops of municipal buildings, swimming pool facilities, sport buildings and schools, including both flat-plate and parabolic solar collectors. Multiple CoM signatories are also taking the opportunity to replace electrical heaters and boilers in public buildings based on solar collectors. As an enabler (M2), CoM signatories are also mobilising purchasing groups to allow the widespread diffusion of solar thermal technology. As authoritative measures, CoM signatories are utilizing their capacities as regulators (M4) to put forth an ordinance for installing solar collectors. Zagreb, Croatia requires the use of solar collectors in all buildings in the health care sector as an action that provides a $\mathrm{CO}_{2}$ reduction of 2077 tonnes and local heat production of $9344 \mathrm{MWh}$ [73]. Loures, Portugal, requires solar thermal systems in $100 \%$ of schools that include south-facing facades and terraces [74]. These and related measures are supporting LAs to reach targets for increasing the use of solar thermal technologies.

\subsection{Wind Energy}

Local ownership of local energy generation is relevant for any energy source. Wind energy represents one of the energy sources in which it is implemented based on such examples as the promotion of locally owned wind turbines (e.g., Ringkøbing-Skjern, Denmark [75]). In addition, in Nijmegen, the Netherlands, a wind and solar farm was established with citizen cooperation (M2) as a measure with a $\mathrm{CO}_{2}$ reduction of 23,488 tonnes at 1,426€ per tonne and local energy generation of $58,300 \mathrm{MWh}$ [76]. The role of LAs in triggering local energy generation investments was also observed in the case of public procurement of municipality owned wind turbines (M1). In Eskilstuna, Sweden, the public procurement of $4 \times 3.3 \mathrm{MW}$ wind turbines that are owned by the municipality enabled about $40 \%$ of the municipal electricity load to be satisfied from wind energy [77]. In Lund, Sweden, the business model for local ownership is realised based on a co-ownership of wind-power plants [78]. As enablers (M2), CoM signatories are also pursuing the attraction of companies that want to generate electricity from wind energy based on such measures as prioritised case handling and licensing of wind turbines. Land use planning is also valid for wind turbines in which CoM signatories are involved in aspects of the use of regulatory and planning capacities (M4).

\subsection{Hydroelectric Power}

Alongside other renewable energy sources, the use of municipally owned facilities for local energy generation (M1) extends to hydroelectric power. For example, in Ronchi Valsugana, Italy, mini-hydroelectric plants are constructed on municipal waterworks [79]. Other CoM signatories in which mini-hydroelectric power plants are constructed include the Italian cities of Mazzin at $2908 €$ per tonne $\mathrm{CO}_{2}$ reduced [80], Rosà with $2 \times 20 \mathrm{~kW}$ [81] and others in which investment is attracted to realize an in-stream $10 \mathrm{MW}$ tidal hydro power plant. Other cases in the database includes the CoM signatory of Roman in Romania in which an equal amount of electricity that is needed for public building and public lighting loads is generated from a run-of-river hydroelectric plant [82].

\subsection{Bioenergy}

The utilisation of bioenergy for local energy generation can involve the waste and wastewater sectors, as well as the sectors of agriculture and forestry in the vicinity. The diversity of bioenergy sources is similarly represented among the CoM signatories based on local energy generation from bioenergy. Multiple signatories are utilising the opportunity to construct new anaerobic digestion plants in publicly owned waste recovery and treatment companies, which can represent a municipal asset (M1). At the same time, public-private partnerships between the municipality and waste management utilities are being established for the anaerobic digestion of biowaste for CHP-based 
district heating in such signatories as Este, Italy [83]. Similarly, Annicco, Italy, has established a biogas cogeneration plant for electricity and thermal energy provision based on anaerobic digestion that produces $3819 \mathrm{MWh}$ [84]. There are numerous other CoM signatories that have established biogas cogeneration based on zootechnical wastewater and silage cereals and/or a bioenergy (biogas or biomass) driven district heating networks. An example can be given from Banja Luka, Bosnia and Herzegovina, that involves a 6 MW biomass based district heating network [85].

In Bagnolo San Vito, Italy, a consortium for a cogeneration plant based on waste that is produced locally from local consortium companies exemplifies the role of the LA as an enabler (M2). Through the local consortium, 28,350 MWh is generated from sources of local farm sewage and industry at about $1058 €$ per tonne $\mathrm{CO}_{2}$ reduced [86]. In signatory municipalities, such as Liepāja, Lithuania, the installation of wood chip boilers in the CHP plant that produces 22,550 MWh is providing carbon neutral district heating at about $1934 €$ per tonne $\mathrm{CO}_{2}$ reduced [87]. In Málaga, Spain, 120 wells for degassing biogas capture and network piping recovers methane gas from landfills to produce electricity with a cost of about $423 €$ per tonne $\mathrm{CO}_{2}$ reduced [67]. The practice of collecting and recycling used cooking oil for biodiesel production and the use of biomethane in waste collection trucks are other examples that link various sources of waste with an energy service in the transport sector. As can be observed from these examples, CoM signatories are directly involved in promoting the use of bioenergy for local energy generation as well as alternative fuel for vehicles.

\subsection{Geothermal Energy}

The availability of high-, medium- or low-grade geothermal energy potential is shaping the local response by CoM signatories in the scope of geothermal energy that is or is yet to be utilised. Some signatories are directly constructing geothermal power plants for local electricity generation or taking the opportunity to use low enthalpy geothermal energy resources for the heating of residential buildings. Other signatories provide City Council grants and subsidies to renewable energy technologies, including PV, solar thermal, biomass and ground source heat pumps.

\subsection{Multiple Renewable Energy Sources}

The orchestration of multiple renewable energy sources is an asset for reaching such targets as net-zero or positive energy targets at the local level in the path of decarbonising the energy sector. In turn, it is important that all modes of urban energy and climate governance are also orchestrated in this direction. In aspects of municipal self-governing (M1), public buildings that are self-sufficient based on on-site renewable energy include a self-sufficient town hall based on bioenergy and PV in Baradili, Italy [88]. A widespread measure among CoM signatories is the application of bioclimatic design principles and renewable energy utilization in public buildings and/or public social housing complexes. Buildings are renovated and equipped with solar thermal collectors and/or biomass in Karlovac, Croatia, with 50\% city co-financing [89], and Kozani, Greece, has attained a daycare center that utilises solar and geothermal energy alongside bioclimatic and healthy building design [90].

One of the most prevalent measures among CoM signatories is the purchasing of certified renewable power for public buildings and public lighting. A joint framework agreement for purchasing additional $100 \%$ green electricity is also implemented among multiple signatories in the Province of Limburg in the Netherlands. As enablers (M2), LAs are actively involved in awareness building activities, including experimental sessions on renewable energy for students and training campaigns organised by the local energy utilities and agencies. As providers (M3), LAs can be involved in the provision of grants for solar collector and heat pump installations, e.g., Alken, Belgium [91], and subsidies to renewable heat sources in residential buildings, e.g., 25\% in Gdynia, Poland [92]. Numerous other CoM signatories established clean technology funds for renewables at the local level or co-financing schemes between local and regional authorities for public energy upgrading. These include a co-financing scheme in Castelnuovo Rangone, Italy, for solar thermal systems [93]. 
Complementary aspects of regulation and planning (M4) include measures for promoting distributed energy generation based on Urban Building Regulations and authorization procedures.

Demonstrations of net or nearly zero energy buildings is another means of stimulating the local ecosystem for contributions to local energy generation, which include net zero-energy public schools (M1) in Göteborg, Sweden [94], and the Viikki Environment House as a nearly zero-energy office in Helsinki, Finland, with multiple renewable energy sources and district heating connection [95], among others. A pilot public school built according to the Nearly Zero Energy Standard in the Winkelomheide parish of Geel, Belgium [96], and a co-financing of a near zero-energy school building (Scuola Pascoli) with local and national funds represent the interaction of policy tools.

Brownfield urban developments with renewable energy technologies for sustainable districts are rapidly closing the gap between local energy generation and urban planning. In the CoM signatory of Ravenna, Italy, a former port and industrial area is transformed into a new sustainable district [97]. Other examples include onshore power supply based on the renewable energy mix to docking ships in the port to displace fossil fuel usage [94] while in Stockholm, Sweden, the Sustainable Järva project involves $10,000 \mathrm{~m}^{2}$ of solar cells [98]. Such measures combine multiple governance modes at the local level, including M2 based on an enabling role for urban foresight and planning as M4.

\subsection{Combined Heat and Power}

The simultaneous production of heat and power in cogeneration plants is being implemented in municipal buildings as a form of municipal self-governing (M1). Biomass-based combined heat and power plants are also contributing to local energy generation in CoM signatories, including $340 \mathrm{GWh}_{\mathrm{t}}$ and $130 \mathrm{GWh}_{\mathrm{e}}$ in Jönköping, Sweden [99]. Other cogeneration plants are being modernised, including fuel flexibility to run on waste and bioenergy, such as in Västerås, Sweden [100]. Low energy houses will also be connected to a low-temperature district heating network. As the provider of energy services, utility companies are also investing in new cogeneration plants with both district heating and cooling infrastructure. In Fürstenfeldbruck, Denmark, the roof of a near $\mathrm{CO}_{2}$-neutral public CHP plant is also co-located with PV panels for extra electricity supply [71]. In some CoM signatories, subsidies for CHP electricity production take place as a relevant policy measure (M3).

\subsection{District Heating and/or Cooling}

The presence of a district heating and/or cooling plants and networks either connected to such plants or CHP are an asset to support local energy generation in CoM signatories. One of the policy measures that LAs have in their authority is to establish a contract to connect municipal buildings and schools to the district heating network (M1 and M4). In Milan, Italy, such a contract is also combined with a commitment to invest $10 \%$ of the contract sum to energy retrofitting and maintenance [101]. In other cases, LAs have cooperated with the local energy utility to establish a district heating network (M2). Other CoM signatories provide initiatives to increase the purchased volume of energy from the district heating network, including subsidies and obligations for connection to district heating (M3 and M4). The interconnection of district heating networks and extension of distribution piping are other measures that require urban planning and regulation.

Good practices in the database include the Marstal District Heating in Aeroe, Denmark, that contains large-scale solar thermal solutions in district heating systems [102] and Kristianstad, Sweden, in which the connection of buildings to the district heating network is increased [103]. Public buildings in Vittorio Veneto, Italy, will have integrated heating systems [104] (M1) and the share of renewable energy sources in the district heating network will increase from $40 \%$ to $95 \%$ in Ringsted, Denmark, based on local planning [105] (M4). In addition to district heating works, the connection of buildings and industries to the district cooling network includes an energy efficient data center with PV on the server hall roof in Växjö, Sweden [106]. District networks also enable access to sources of waste heat. Among CoM signatories, residual heat from urban wastewater is utilised in Aachen, Germany [107], waste heat from the local steel industry is recovered in Finspång, Sweden [108], and the 
use of natural gas is substituted based on the connection of buildings to a district heating network that utilises the available waste heat from a pulp mill in Judenburg, Austria [109].

In addition to establishing and extending district energy networks, their modernisation and rehabilitation is another aspect that requires action based on urban governance. In Bielsko-Biala, Poland, the remote monitoring of pipelines and insulation has reduced heat losses from $30 \%$ to $12 \%$ [110]. In Rijeka, Croatia, thermal energy distributors and thermostatic radiator valves were installed in the district heating network based on city co-financing with an estimated impact of saving 3140 tonnes of $\mathrm{CO}_{2}$ emissions [111] (M3). In Riga, Latvia, flue-gas heat recovery is applied to increase the efficiency of heat production [112]. As a relatively unique case, Lerum, Sweden, has cooperated with local actors as an enabler (M2) to establish noise barriers for road and rail traffic that is equipped with solar energy collectors to support local energy generation for the district heating system [113].

\subsection{Smart Electricity Grids}

In addition to thermal grids, the policy measures of LAs have involved the stimulation of smart electricity grids, including cooperation with the district network operator for demand side management. In Glasgow, the United Kingdom, monitoring and response to peak load in public buildings are implemented towards a future smart grid (M1). Local, regional, national and EU funds are also being utilised to finance pilot projects on smart grids and demonstration sites.

\subsection{Waste and Water Management}

The efficient planning of available waste flows can allow LAs to oversee that higher recycling and bioenergy stocks are obtained. Numerous CoM signatories are upholding the need for separate waste collection to increase the recycling of municipal solid waste and the use of organic waste for biogas production (M4), which is also supported by awareness-building (M2). In Lakatamia, Cyprus, green waste is used for the production of compost and pellets [114]. In other signatories, organic waste is chosen to be utilised for composting rather than incineration in waste-to-energy plants.

In cross-cutting aspects of water management and local energy generation, renewable sources are integrated for supplying power to pumping tapwater. In addition, electricity usage for pumping is reduced based on reductions in water losses in the drinking-water distribution network in Seixal [115] and Bilbao [116], Portugal. In this way, LAs are able to provide more energy-efficient water services (M3). In order to support related aspects of public awareness, Voznesensk in Ukraine established an information system for energy and water use in the public sector (M1) [117]. Wastewater provides a valuable source of bioenergy upon which Neumarkt in der Oberpfalz in Germany established a self-sufficient wastewater facility based on methane driven CHP plant [118].

\section{Conclusions}

As the closest level of government to citizens, local authorities play a crucial role in building public support for the European Union's energy and climate goals while deploying more decentralised and integrated energy systems. The European Union Covenant of Mayors initiative has been one of the disrupting phenomena in the arena of transnational initiatives, which have expanded tremendously over the past 10 years. The first version of CoM methodology published in 2010 [119] has been an important guiding document for cities in Europe on the elaboration of SEAPs. After 8 years from the first publication of the CoM guidebook, JRC is in the process of revising the CoM methodology. Gaining the opportunity from this unique momentum, the present work summarises the main methodological updates that are proposed in the new version of the CoM guidebook published in 2018 [120-122].

It is important for local authorities to have a clear framework and pathway for the redaction of the climate action plans; therefore, this updated methodology and the rationale behind it could be helpful in supporting them. The main aspects developed in this paper relate to: 
- An updated definition of local energy generation, favouring the inclusion of the new developments of distributed generation, especially from renewable energy sources and cogeneration technologies.

- An updated methodology for indirect emission accounting, taking into account the increasing participation of local citizens along with local authorities in the energy transition.

- An updated overview of the EU energy and climate policies influencing local action in energy generation.

- An updated guidance to local authorities on the modes of energy and climate governance. In this process, local authorities have the capacity to support and mobilise action for local energy generation investments. The four modes of urban energy and climate governance are investigated and a policy matrix that summarises the scope of each mode along with the main tools, and exemplary actions to support local energy sustainability are provided.

- The exemplary actions to support local sustainable energy generation can be used to further promote city-to-city policy learning based on the Benchmarks of Excellence. The cities will observe that there are a multitude of approaches that can strengthen urban energy and climate governance in a coherent way, including the application of multiple modes simultaneously for combined impact.

Within the Covenant of Mayors framework, it is highly advisable that the CoM signatories utilise the opportunity of revision based on the new version of the CoM guidebook to update and strengthen their climate action. The leadership of cities is crucial to the success of climate mitigation action to address the urgency of global climate change. Cities have shown a significant potential for greater leadership through accelerated action to support local energy generation in the pathway of realising the sustainable energy transition.

Author Contributions: Conceptualization and methodology: A.K., P.B., S..K.; formal analysis, investigation and writing—original draft preparation: A.K. and S..K.; supervision and project administration: P.B.

Funding: This research received no external funding.

Acknowledgments: We are grateful to the local authorities who make public their engagement in climate action planning through their participation in the Covenant of Mayors initiative. The authors would like to thank European Commission Directorate General for Energy, the CoM Office and JRC colleagues working in the CoM initiative for their support in giving visibility and effectiveness to the effort of cities and local governments in the climate change action. A special acknowledgment to our colleagues Jean François Dallemand and Christian Thiel for reviewing of the CoM methodology and to Gianluca Fulli for discussion on methodological challenges.

Conflicts of Interest: The authors declare no conflict of interest. The views expressed are purely those of the authors and may not in any circumstances be regarded as stating an official position of the European Commission.

\section{Appendix A}

Tables A1-A3 represent policy measures regarding renewable energy source and technology, as well as the relevant modes of urban climate governance where M1 is municipal self-governing, M2 is governing through enabling, M3 is governing by provision and M4 is governing by regulation and planning. 
Table A1. Renewable energy sources.

\begin{tabular}{|c|c|c|c|c|c|}
\hline $\begin{array}{c}\text { Area of } \\
\text { Intervention }\end{array}$ & Policy Measure & M1 & M2 & M3 & M4 \\
\hline \multirow{17}{*}{$\begin{array}{l}\text { Local electricity } \\
\text { generation: }\end{array}$} & $\begin{array}{l}\text { Municipal financing and ownership of PV pilot plants on public buildings (rooftop } \\
\text { PV and building-integrated PV systems) }\end{array}$ & $\sqrt{ }$ & & & \\
\hline & PV installations on the roofs of bus sheds ( $968 \mathrm{~kW}$ in Mantova, Italy) or parking lots & $\sqrt{ }$ & & & \\
\hline & $\begin{array}{l}\text { Construction of a PV park on ground of municipal property at a former landfill site } \\
\text { (994 kW in Torrile, Italy; Évora, Portugal) }\end{array}$ & $\sqrt{ }$ & & & \\
\hline & Concession of surface rights and renting of rooftop areas in public buildings for PV & $\sqrt{ }$ & & $\sqrt{ }$ & \\
\hline & $\begin{array}{l}\text { PV installations in public buildings based on collaboration with the ESCo and } \\
\text { third-party financing for PV systems in school buildings }\end{array}$ & $\sqrt{ }$ & & $\sqrt{ }$ & \\
\hline & $\begin{array}{l}\text { Public-private partnership for Photovoltaic Solar Park (24.2 MW in Coruche, } \\
\text { Portugal) }\end{array}$ & & $\sqrt{ }$ & $\sqrt{ }$ & \\
\hline & City supported photovoltaic campaign & & & & \\
\hline & - One million square metres of solar modules by 2020 (Hannover, Germany) & & $\sqrt{ }$ & $\sqrt{ }$ & \\
\hline & Energy supplier obligations for PV systems & & & & \\
\hline & $\begin{array}{l}\text { - Mandate for PV system installations equal to a given share of the total installed } \\
\text { power in the municipality }\end{array}$ & & & & $\sqrt{ }$ \\
\hline & Municipality bonus for photovoltaic and solar thermal installation on citizen's roof & & & $\sqrt{ }$ & \\
\hline & $\begin{array}{l}\text { Interest-free loans for associations or schools for PV panel installations (Bree, } \\
\text { Belgium) }\end{array}$ & & & $\sqrt{ }$ & \\
\hline & PV systems that supply electric vehicle charging stations (135 kW in Poole, U.K.) & $\sqrt{ }$ & & $\sqrt{ }$ & \\
\hline & $\begin{array}{l}\text { Real time electricity generation data on PV systems of the City Council (Málaga, } \\
\text { Spain) and visual consoles on } \mathrm{CO}_{2} \text { reductions }\end{array}$ & $\sqrt{ }$ & $\sqrt{ }$ & & \\
\hline & $\begin{array}{l}\text { Awareness building and planning supporting tools for solar energy } \\
\text { - Solar land registry for roof-top photovoltaic or solar thermal installations } \\
\text { (Paris, France) } \\
\text { - Solar chart for identifying preferable areas for solar energy technologies } \\
\text { (Lisbon, Portugal) } \\
\text { - Solar roof cadasters (Bremen, Germany; Fürstenfeldbruck, Germany; } \\
\text { Hannover, Germany; Barcelona, Spain, and others) }\end{array}$ & & $\sqrt{ }$ & $\sqrt{ }$ & $\sqrt{ }$ \\
\hline & Public awareness to reach annual increase targets for PV in the private buildings & & $\sqrt{ }$ & & $\sqrt{ }$ \\
\hline & Land use planning for utility-scale PV plants in the municipality & & & & $\sqrt{ }$ \\
\hline \multirow{4}{*}{$\begin{array}{l}\text { Local heat } \\
\text { generation: }\end{array}$} & $\begin{array}{l}\text { Solar collectors on rooftops of municipal buildings, swimming pool facilities, sport } \\
\text { buildings and schools (including flat-plate and parabolic solar collector installations) } \\
\text { - } \quad \text { Replacement of electrical heaters and boilers in public buildings }\end{array}$ & $\sqrt{ }$ & & & \\
\hline & Purchasing groups to allow widespread diffusion of solar thermal technology & & $\sqrt{ }$ & & \\
\hline & $\begin{array}{l}\text { Ordinance for installing solar collectors } \\
\text { - Solar collectors in all buildings in the health care sector (Zagreb, Croatia) } \\
\text { - Solar thermal systems in } 100 \% \text { of schools that include south-facing facades and } \\
\text { terraces (Loures, Portugal) }\end{array}$ & & & & $\sqrt{ }$ \\
\hline & Targets to increase the area of solar thermal in the municipality & & & & $\sqrt{ }$ \\
\hline
\end{tabular}


Table A1. Cont.

\begin{tabular}{|c|c|c|c|c|c|}
\hline $\begin{array}{c}\text { Area of } \\
\text { Intervention }\end{array}$ & Policy Measure & M1 & M2 & M3 & M4 \\
\hline \multirow{6}{*}{$\begin{array}{l}\text { Local electricity } \\
\text { generation: } \\
\text { Wind energy }\end{array}$} & $\begin{array}{l}\text { Public procurement of municipality owned wind turbines }(4 \times 3.3 \mathrm{MW} \text { in } \\
\text { Eskilstuna, Sweden at } 40 \% \text { of the municipal electricity load })\end{array}$ & $\sqrt{ }$ & & & \\
\hline & Installation of wind power farms & & & & \\
\hline & $\begin{array}{l}\text { - Co-ownership of wind-power plants (municipal company in Lund, Sweden) } \\
\text { - } \quad \text { Promotion of locally owned wind turbines (Ringkøbing-Skjern, Denmark) }\end{array}$ & $\sqrt{ }$ & $\sqrt{ }$ & & \\
\hline & Wind and solar farm with citizen cooperation (Nijmegen, Netherlands) & & $\sqrt{ }$ & & \\
\hline & Attraction of companies that want to generate electricity from wind energy & & & & \\
\hline & - $\quad$ Prioritised case handling and licensing of wind turbines & & $\sqrt{ }$ & & \\
\hline \multirow{6}{*}{$\begin{array}{l}\text { Local electricity } \\
\text { generation: } \\
\text { Hydroelectric } \\
\text { power }\end{array}$} & Mini-hydro plants on municipal waterworks & & & & \\
\hline & - $\quad$ Ronchi Valsugana, Italy & $\sqrt{ }$ & & & \\
\hline & Hydroelectric power plant construction (Manerbio, Italy; Mazzin, Italy; Rosà, Italy) & $\sqrt{ }$ & $\sqrt{ }$ & & \\
\hline & Attraction of investment to realize an in-stream tidal hydro power plant (10 MW) & & $\sqrt{ }$ & & \\
\hline & Run-of-river hydroelectric plants & & & & \\
\hline & $\begin{array}{l}\text { - Produces the amount of electricity needed for public building and public } \\
\text { lighting loads (Roman, Romania) }\end{array}$ & $\sqrt{ }$ & & & \\
\hline \multirow{9}{*}{ Bioenergy } & Biogas cogeneration based on zootechnical wastewater and silage cereals & & & $\sqrt{ }$ & \\
\hline & Biogas-driven district heating network & & & $\sqrt{ }$ & \\
\hline & $\begin{array}{l}\text { Biomass-based district heating network and/or biomass boilers for replacing diesel } \\
\text { boilers (local wood chips }<60 \mathrm{~km} \text { from sustainable management of forests) }\end{array}$ & & & & \\
\hline & - $\quad 6 \mathrm{MW}$ in Banja Luka, Bosnia Herzegovina & & & $\sqrt{ }$ & \\
\hline & Recovery of methane gas from landfills to produce electricity based on gas engines & & & & \\
\hline & - $\quad 120$ wells degassing biogas capture and network piping (Málaga, Spain) & $\sqrt{ }$ & & $\sqrt{ }$ & \\
\hline & $\begin{array}{l}\text { Consortium for a cogeneration plant based on biomass certified as sustainable } \\
\text { (waste produced locally or from local consortium companies (Bagnolo San Vito, } \\
\text { Italy) }\end{array}$ & & $\sqrt{ }$ & $\sqrt{ }$ & \\
\hline & Installation of wood chip boilers in the CHP plant for carbon neutral district heating & & & & \\
\hline & - $\quad$ Fuel switching in Liepāja, Lithuania, and other signatory municipalities & & & $\sqrt{ }$ & \\
\hline
\end{tabular}


Table A1. Cont.

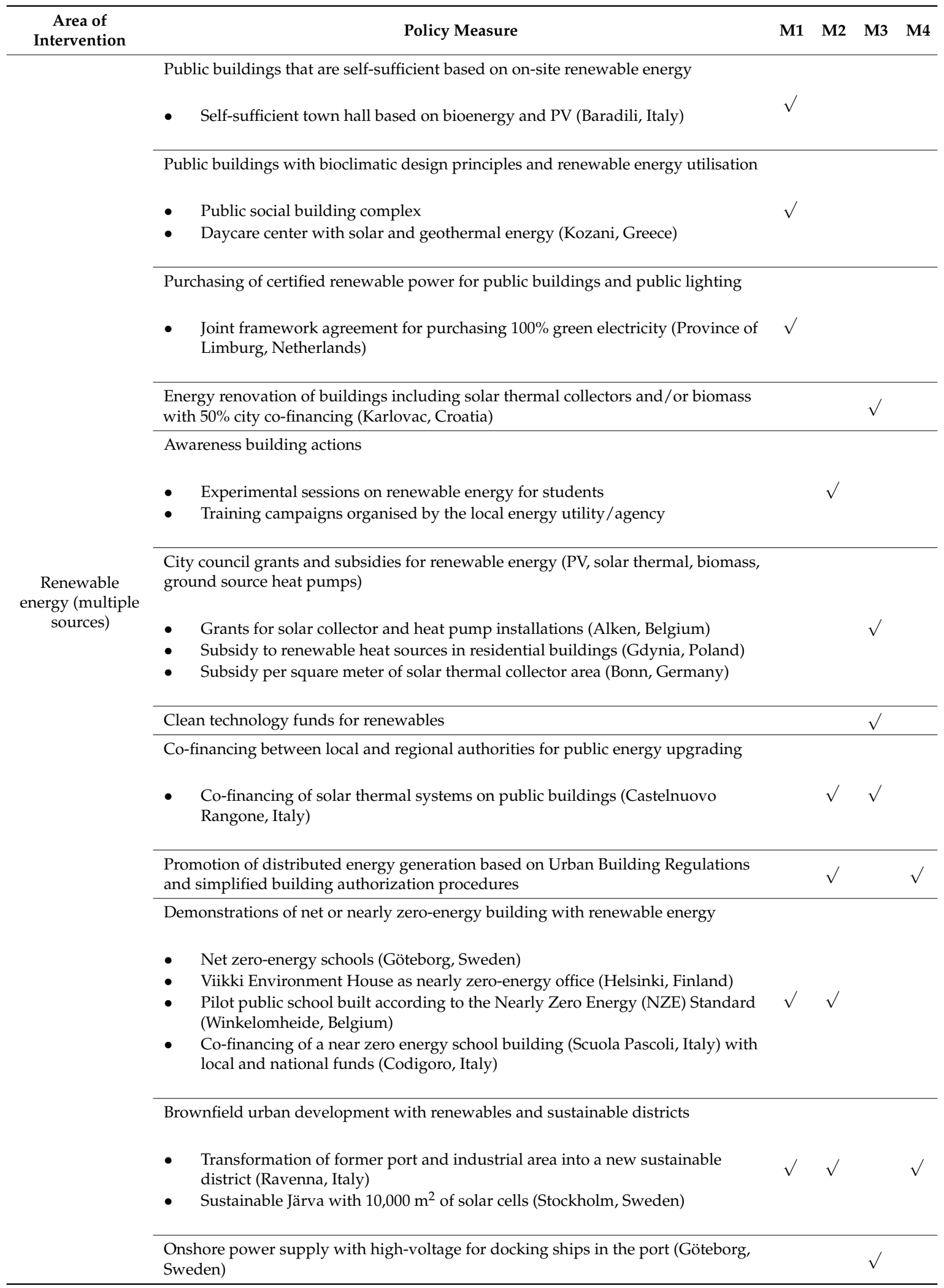


Table A2. Combined heat and power, district heating and cooling and smart grids.

\begin{tabular}{|c|c|c|c|c|c|}
\hline $\begin{array}{l}\text { Area of } \\
\text { Intervention }\end{array}$ & Policy Measure & M1 & M2 & M3 & M4 \\
\hline \multirow{6}{*}{$\begin{array}{l}\text { Combined heat } \\
\text { and power }\end{array}$} & Cogeneration plant for municipal buildings & $\sqrt{ }$ & & & \\
\hline & $\begin{array}{l}\text { Biomass-based combined heat and power plant to support the district heating system } \\
\text { (Jönköping, Sweden, with } 340 \mathrm{GWh}_{\mathrm{t}} \text { and } 130 \mathrm{GWh}_{\mathrm{e}} \text { ) }\end{array}$ & & & $\sqrt{ }$ & \\
\hline & $\begin{array}{l}\text { Modernization of the cogeneration plant with fuel flexibility for waste and bioenergy } \\
\text { (Västerås, Sweden) }\end{array}$ & & & $\sqrt{ }$ & \\
\hline & $\begin{array}{l}\text { Investment of the public utility company in a new cogeneration plant with both district } \\
\text { heating and cooling infrastructure }\end{array}$ & & & & \\
\hline & $\begin{array}{l}\text { - Bioenergy based plant with co-location of PV panels on the roof of the plant } \\
\text { (Fürstenfeldbruck, Denmark) }\end{array}$ & $\sqrt{ }$ & & $\sqrt{ }$ & \\
\hline & Subsidies for CHP electricity production & & & $\sqrt{ }$ & \\
\hline \multirow{2}{*}{$\begin{array}{l}\text { District } \\
\text { heating/cooling } \\
\text { plant }\end{array}$} & $\begin{array}{l}\text { Large-scale solar thermal solutions in district heating systems (Marstal District Heating in } \\
\text { Aeroe, Denmark) }\end{array}$ & & & $\sqrt{ }$ & \\
\hline & Flue-gas heat recovery to increase efficiency of heat production (Riga, Latvia) & & & $\sqrt{ }$ & \\
\hline \multirow{16}{*}{$\begin{array}{l}\text { District } \\
\text { heating/cooling } \\
\text { network }\end{array}$} & $\begin{array}{l}\text { Contract to connect municipal buildings and schools to the district heating network } \\
\text { - Commitment to invest } 10 \% \text { of the contract sum to energy retrofitting and } \\
\text { maintenance (Milan, Italy) }\end{array}$ & $\sqrt{ }$ & & & $\sqrt{ }$ \\
\hline & Integrated heating systems between public buildings (Vittorio Veneto, Italy) & $\sqrt{ }$ & & & \\
\hline & Initiative to increase the purchased volume of energy from the district heating network & & & & \\
\hline & - Subsidies and/or obligations for connection to district heating & & & $\sqrt{ }$ & $\sqrt{ }$ \\
\hline & $\begin{array}{l}\text { Modernization and rehabilitation of district heating and/or cooling networks } \\
\text { - Remote monitoring of pipelines and insulation to reduce heat losses ( } 30 \% \text { to } 12 \% \text { in } \\
\text { Bielsko-Biala, Poland) }\end{array}$ & & & $\sqrt{ }$ & \\
\hline & $\begin{array}{l}\text { Co-financing of thermal energy distributors and thermostatic radiator valves in the } \\
\text { district heating network (Rijeka, Croatia) }\end{array}$ & & & $\sqrt{ }$ & \\
\hline & $\begin{array}{l}\text { Connection of low energy houses to a low-temperature district heating network (Västerås, } \\
\text { Sweden) }\end{array}$ & & & $\sqrt{ }$ & \\
\hline & $\begin{array}{l}\text { Connection of buildings and industries to the district cooling network } \\
\text { - } \quad \text { Energy efficient data center with PV on the server hall roof (Växjö, Sweden) }\end{array}$ & & & $\sqrt{ }$ & \\
\hline & Utilisation of residual heat from urban wastewater (e.g., Aachen, Denmark, and others) & & & $\sqrt{ }$ & \\
\hline & $\begin{array}{l}\text { Utilisation of industrial waste heat } \\
\text { - Recovery of waste heat from the local steel industry (Finspång, Sweden) } \\
\text { - Substitution of the use of natural gas based on the use of waste heat from a pulp mill } \\
\text { (Judenburg, Austria) }\end{array}$ & & & $\sqrt{ }$ & \\
\hline & $\begin{array}{l}\text { Co-operation to establish noise barriers for road and rail traffic equipped with solar } \\
\text { energy collectors to support the local district heating system (Lerum, Sweden) }\end{array}$ & & $\sqrt{ }$ & & \\
\hline & Cooperation with the local energy utility to establish a district heating network & & $\sqrt{ }$ & & \\
\hline & Interconnection of district heating networks and extension of distribution piping & & & $\sqrt{ }$ & $\sqrt{ }$ \\
\hline & $\begin{array}{l}\text { Urban planning to increase the connection of buildings to the municipally-owned district } \\
\text { heating network (Kristianstad, Sweden) }\end{array}$ & & & $\sqrt{ }$ & $\sqrt{ }$ \\
\hline & Increase in the share of renewable energy sources in the district heating network & & & & \\
\hline & - From $40 \%$ to $95 \%$ in Ringsted, Denmark & & & & $\sqrt{ }$ \\
\hline \multirow{3}{*}{$\begin{array}{l}\text { Smart electricity } \\
\text { grids }\end{array}$} & Cooperation with the district network operator for demand side management & & & & \\
\hline & $\begin{array}{l}\text { - Monitoring and response to peak load in public buildings towards a future smart } \\
\text { grid (Glasgow, U.K.) }\end{array}$ & $\sqrt{ }$ & $\sqrt{ }$ & & \\
\hline & $\begin{array}{l}\text { Financing of pilot projects on smart grids and allocation of local demonstration sites (local, } \\
\text { regional, national and EU funds) }\end{array}$ & & & $\sqrt{ }$ & \\
\hline
\end{tabular}


Table A3. Waste and water management (including wastewater treatment).

\begin{tabular}{|c|c|c|c|c|c|}
\hline $\begin{array}{l}\text { Area of } \\
\text { Intervention }\end{array}$ & Policy Measure & M1 & M2 & M3 & M4 \\
\hline \multirow{3}{*}{$\begin{array}{l}\text { Waste } \\
\text { management }\end{array}$} & $\begin{array}{l}\text { Separate waste collection to increase the recycling of municipal solid waste and the } \\
\text { use of organic waste for biogas production }\end{array}$ & & & $\sqrt{ }$ & $\sqrt{ }$ \\
\hline & Use of green waste for the production of compost and pellets (Lakatamia, Cyprus ) & & & $\sqrt{ }$ & $\sqrt{ }$ \\
\hline & Utilisation of organic waste for composting rather than waste-to-energy incineration & & & $\sqrt{ }$ & $\sqrt{ }$ \\
\hline $\begin{array}{l}\text { Wastewater } \\
\text { treatment } \\
\text { plants }\end{array}$ & $\begin{array}{l}\text { Self-sufficient wastewater facility based on methane driven combined heat and power } \\
\text { plant (Neumarkt in der Oberpfalz, Germany) }\end{array}$ & & & $\sqrt{ }$ & $\sqrt{ }$ \\
\hline \multirow{3}{*}{$\begin{array}{l}\text { Water } \\
\text { management }\end{array}$} & Integration of renewable sources for supplying power to pumping tapwater & & & $\sqrt{ }$ & $\sqrt{ }$ \\
\hline & $\begin{array}{l}\text { Reduction in electricity usage for pumping based on reductions in water losses in the } \\
\text { drinking-water distribution network(Seixal, Portugal; Bilbao, Portugal) }\end{array}$ & & & $\sqrt{ }$ & $\sqrt{ }$ \\
\hline & $\begin{array}{l}\text { Information system for energy and water use in the public sector (Voznesensk, } \\
\text { Ukraine) }\end{array}$ & $\sqrt{ }$ & $\sqrt{ }$ & & \\
\hline
\end{tabular}

\section{References}

1. Gordon, J.D. The Politics of Accountability in Networked Urban Climate Governance. Glob. Environ. Politics 2016, 16, 82-100. [CrossRef]

2. Byrne, J.; Taminiau, J.; Seo, J.; Lee, J.; Shin, S. Are solar cities feasible? A review of current research. Int. J. Urban Sci. 2017, 21, 239-256. [CrossRef]

3. Bansard, J.S.; Pattberg, P.H.; Widerberg, O. Cities to the rescue? Assessing the performance of transnational municipal networks in global climate governance. Int. Environ. Agreem. Politics Law Econ. 2017, 17, 229-246. [CrossRef]

4. Christoforidis, G.C.; Chatzisavvas, K.C.; Lazarou, S.; Parisses, C. Covenant of Mayors initiative-Public perception issues and barriers in Greece. Energy Policy 2013, 60, 643-655. [CrossRef]

5. Pablo-Romero, M.; Sánchez-Braza, A.; González-Limón, J.M. Covenant of Mayors: Reasons for Being an Environmentally and Energy Friendly Municipality. Rev. Policy Res. 2015, 32, 576-599. [CrossRef]

6. Lombardi, M.; Pazienza, P.; Rana, R. The EU environmental-energy policy for urban areas: The Covenant of Mayors, the ELENA program and the role of ESCos. Energy Policy 2016, 93, 33-40. [CrossRef]

7. Fecondo, P.; Moca, G. The ELENA Programme in the Province of Chieti-A Public Private Partnership Best Practice Improving Energy Efficiency of Buildings and Public Lighting Systems. J. Sustain. Dev. Energy Water Environ. Syst. 2015, 3, 230-244. [CrossRef]

8. Melica, G.; Bertoldi, P.; Kona, A.; Iancu, A.; Rivas, S.; Zancanella, P. Multilevel governance of sustainable energy policies: The role of regions and provinces to support the participation of small local authorities in the Covenant of Mayors. Sustain. Cities Soc. 2018, 39, 729-739. [CrossRef]

9. Rashidi, K.; Patt, A. Subsistence over symbolism: The role of transnational municipal networks on cities' climate policy innovation and adoption. Mitig. Adapt. Strateg. Glob. Chang. 2017, 23, 507-523. [CrossRef]

10. Bulkeley, H.; Andonova, L.; Bäckstrand, K.; Betsill, M.; Compagnon, D.; Duffy, R.; Kolk, A.; Hoffmann, M.; Levy, D.; Newell, P.; et al. Governing climate change transnationally: Assessing the evidence from a database of sixty initiatives. Environ. Plan. C Gov. Policy 2012, 30, 591-612. [CrossRef]

11. Kern, K. Cities as leaders in EU multilevel climate governance: Embedded upscaling of local experiments in Europe. Environ. Politics 2019, 28, 125-145. [CrossRef]

12. Broto, V.C. Urban Governance and the Politics of Climate change. World Dev. 2017, 93, 1-15. [CrossRef]

13. Pablo-Romero, M.; Pozo-Barajas, R.; Sánchez-Braza, A. Understanding local $\mathrm{CO}_{2}$ emissions reduction targets. Renew. Sustain. Energy Rev. 2015, 48, 347-355. [CrossRef]

14. Khan, F.; Sovacool, B.K. Testing the efficacy of voluntary urban greenhouse gas emissions inventories. Clim. Chang. 2016, 139, 141-154. [CrossRef]

15. Pablo-Romero, M.; Pozo-Barajas, R.; Sánchez-Braza, A. Analyzing the effects of Energy Action Plans on electricity consumption in Covenant of Mayors signatory municipalities in Andalusia. Energy Policy 2016, 99, 12-26. [CrossRef]

16. Croci, E.; Lucchitta, B.; Janssens-Maenhout, G.; Martelli, S.; Molteni, T. Urban $\mathrm{CO}_{2}$ mitigation strategies under the Covenant of Mayors: An assessment of 124 European cities. J. Clean. Prod. 2016, 169, 161-177. [CrossRef] 
17. Yu, W.; Pagani, R.; Huang, L. $\mathrm{CO}_{2}$ emission inventories for Chinese cities in highly urbanized areas compared with European cities. Energy Policy 2012, 47, 298-308. [CrossRef]

18. Delponte, I.; Pittaluga, I.; Schenone, C. Monitoring and evaluation of Sustainable Energy Action Plan: Practice and perspective. Energy Policy 2017, 100, 9-17. [CrossRef]

19. Leal, V.M.S.; Azevedo, I. Setting targets for local energy planning: Critical assessment and a new approach. Sustain. Cities Soc. 2016, 26, 421-428. [CrossRef]

20. Dall'O', G.; Norese, M.; Galante, A.; Novello, C. A Multi-Criteria Methodology to Support Public Administration Decision Making Concerning Sustainable Energy Action Plans. Energies 2013, 6, 4308-4330. [CrossRef]

21. Di Leo, S.; Salvia, M. Local strategies and action plans towards resource efficiency in South East Europe. Renew. Sustain. Energy Rev. 2017, 68, 286-305. [CrossRef]

22. Gagliano, A.; Nocera, F.; D'Amico, A.; Spataru, C. Geographical information system as support tool for sustainable Energy Action Plan. Energy Procedia 2015, 83, 310-319. [CrossRef]

23. Kilkiş, Ş. Sustainable development of energy, water and environment systems index for Southeast European cities. J. Clean. Prod. 2016, 130, 222-234. [CrossRef]

24. Kılkıs, Ş. Composite index for benchmarking local energy systems of Mediterranean port cities. Energy 2015, 92, 622-638. [CrossRef]

25. Doukas, H.; Papadopoulou, A.; Savvakis, N.; Tsoutsos, T.; Psarras, J. Assessing energy sustainability of rural communities using Principal Component Analysis. Renew. Sustain. Energy Rev. 2012, 16, 1949-1957. [CrossRef]

26. Messori, G.; Morello, E.; Caserini, S. Indice di Implementazione dei Piani d'Azione per l'Energia Sostenibile: Metodologia e Applicazione alla Città Metropolitana di Milano. Ing. dell'Ambiente 2018, 5, 302-320.

27. Seto, K.C.; Dhakal, S.; Bigio, A.; Blanco, H.; Delgado, G.C.; Dewar, D.; Huang, L.; Inaba, A.; Kansal, A.; Lwasa, S.; et al. Chapter 12. Human Settlements, Infrastructure, and Spatial Planning. In Edenhofer, Climate Change 2014: Mitigation of Climate Change. Contribution of Working Group III to the Fifth Assessment Report of the Intergovernmental Panel on Climate Change; Cambridge University Press: Cambridge, UK, 2014.

28. Arup and C40 Cities Climate Leadership Group. Global Aggregation of City Climate CommitmentsMethodological Review; ARUP: London, UK, 2014.

29. Reckien, D.; Flacke, J.; Dawson, R.J.; Heidrich, O.; Olazabal, M.; Foley, A.; Hamann, J.J.; Orru, H.; Salvia, M.; Hurtado, S.D.G.; et al. Climate change response in Europe: what's the reality? Analysis of adaptation and mitigation plans from 200 urban areas in 11 countries. Clim. Chang. 2014, 122, 331-340. [CrossRef]

30. Erickson, P.; Tempest, K. Advancing Climate Ambition: How City-Scale Actions Can Contribute to Global Climate Goals. No. 2014-6; Stockholm Environment Institute: Stockholm, Sweden, 2014.

31. International Energy Agency (IEA). Energy Technology Perspectives 2014; International Energy Agency: Paris, France, 2014.

32. Ürge-Vorsatz, D.; Petrichenko, K.; Antal, M.; Staniec, M.; Labelle, M.; Ozden, E.; Labzina, E. Best Practice Policies for Low Energy and Carbon Buildings: A Scenario Analysis; Research report prepared by the Center for Climate Change and Sustainable Policy (3CSEP) for the Global Buildings Performance Network May 2012; Central European University Press: Budapest, Hungary, 2012.

33. Replogle, M.A.; Fulton, L.M. A Global High Shift Scenario: Impacts and Potential for More Public Transport, Walking, and Cycling with Lower Car Use; The National Academies of Sciences, Engineering, and Medicine: Washington, DC, USA, 2014; p. 35.

34. Kona, A.; Bertoldi, P.; Monforti-Ferrario, F.; Rivas, S.; Dallemand, J.F. Covenant of mayors signatories leading the way towards 1.5 degree global warming pathway. Sustain. Cities Soc. 2018, 41, 568-575. [CrossRef]

35. Widerberg, O.; Pattberg, P. Accountability Challenges in the Transnational Regime Complex for Climate Change. Rev. Policy Res. 2017, 34, 68-87. [CrossRef]

36. Kona, A.; Melica, G.; Bertoldi, P.; Calvete, S.R.; Koffi, B.; Iancu, A.; Zancanella, P.; Janssens-Maenhout, G.; Dallemand, J.F. Covenant of Mayors in Figures: 8-Year Assessment; Publications Office of the European Union: Luxembourg, 2017.

37. Bertoldi, P.; Kona, A.; Rivas, S.; Dallemand, J.F. Towards a Global Comprehensive and Transparent Framework for Cities and Local Governments enabling an Effective Contribution to the Paris Climate Agreement. Curr. Opin. Environ. Sustain. 2018, 30, 67-74. [CrossRef]

38. Ackermann, T. Distributed generation: A definition. Electr. Power Syst. Res. 2001, 57, 195-204. [CrossRef] 
39. Von Wirth, T.; Gislason, L.; Seidl, R. Distributed energy systems on a neighborhood scale: Reviewing drivers of and barriers to social acceptance. Renew. Sustain. Energy Rev. 2018, 82, 2618-2628. [CrossRef]

40. Singh, B.; Sharma, J. A review on distributed generation planning. Renew. Sustain. Energy Rev. 2017, 76, 529-544. [CrossRef]

41. L'Abbate, A.; Fulli, G.; Starr, F.; Peteves, S. Distributed Power Generation in Europe: Technical Issues for Further Integration; JRC European Commission Scientific and Technical Report; European Commission: Brussels, Belgium, 2007.

42. Klimscheffskij, M.; van Craenenbroeck, T.; Lehtovaara, M.; Lescot, D.; Tschernutter, A.; Raimundo, C.; Seebach, D.; Timpe, C. Residual Mix Calculation at the Heart of Reliable Electricity Disclosure in Europe-A Case Study on the Effect of the RE-DISS Project. Energies 2015, 8, 4667-4696. [CrossRef]

43. WRI. GHG Protocol Scope 2 Guidance; WRI: Washington, DC, USA, 2015; p. 151.

44. International Energy Agency (IEA). Emission Factors; International Energy Agency (IEA): Paris, France, 2018.

45. IPCC. Emission Factor Database; IPCC: Geneva, Switzerland, 2018.

46. ISPRA. Fattori di Emissione Atmosferica di gas ad Effetto Serra e Altri gas nel Settore Elettrico; ISPRA: Rome, Italy, 2018.

47. Covenantofmayors.eu. Available online: https://www.covenantofmayors.eu/support/library.html (accessed on 1 December 2018).

48. Eurostat/Web/Energy/Data/Shares. Available online: http://ec.europa.eu/eurostat/web/energy/data/ shares (accessed on 1 December 2018).

49. Bertoldi, P.; Huld, T. Tradable certificates for renewable electricity and energy savings. Energy Policy 2006, 34, 212-222. [CrossRef]

50. Fawcett, T.; Rosenow, J.; Bertoldi, P. Energy efficiency obligation schemes: Their future in the EU. Energy Effic. 2019, 12, 57-71. [CrossRef]

51. Kern, K.; Bulkeley, H. Cities, Europeanization and multi-level governance: Governing climate change through transnational municipal networks. J. Common Mark. Stud. 2009, 47, 309-332. [CrossRef]

52. Kern, K.; Alber, G. Governing Climate Change in Citites: Modes of Urban Climate Governance in Multi-level Systems. In Proceedings of the Competitive Cities and Climate Change, OECD Conference Proceedings, Milan, Italy, 9-10 October 2008; pp. 171-196.

53. Covenant of Mayors for Climate and Energy Signatories' Good Practices. Available online: https://www. covenantofmayors.eu/plans-and-actions/good-practices.html (accessed on 1 December 2018).

54. Young, J.; Brans, M. Analysis of factors affecting a shift in a local energy system towards $100 \%$ renewable energy community. J. Clean. Prod. 2017, 169, 117-124. [CrossRef]

55. Energy Efficiency Training of Trainers (EETT). Available online: https:/ / ec.europa.eu/energy/intelligent/ projects/en/projects / eett. (accessed on 1 December 2018).

56. Herbes, C.; Brummer, V.; Rognli, J.; Blazejewski, S.; Gerick, N. Responding to policy change: New business models for renewable energy cooperatives-Barriers perceived by cooperatives' members. Energy Policy 2017, 109, 82-95. [CrossRef]

57. Verda, V.; Caccin, M.; Kona, A. Thermoeconomic cost assessment in future district heating networks. Energy 2016, 117, 485-491. [CrossRef]

58. Solar Thermal Ordinances = Making A Commitment to Local Sustainable Energy. Available online: http: / / www.estif.org/fileadmin/estif/content/projects/prosto/downloads/prostobrochure.pdf (accessed on 1 December 2018).

59. CEMR, Climate Alliance, Energie-Cités. Guide for Local and Regional Governments 'Save the Energy, Save the Climate, Save Money'; CEMR: Brussels, Belgium, 2008.

60. Energy Union Research, Innovation and Competitiveness Priority, No1 in Renewable Energy. Available online: https://setis.ec.europa.eu/low-carbon-technologies/no1-renewables (accessed on 1 December 2018).

61. Covenant of Mayors Good Practices Database. Available online: https://www.covenantofmayors.eu/plansand-actions / good-practices.html (accessed on 1 December 2018).

62. Mantova Key Actions. Available online: https://www.covenantofmayors.eu/about/covenant-community/ signatories / key-actions.html?scity_id=6703 (accessed on 1 December 2018).

63. Évora Key Actions. Available online: https://www.covenantofmayors.eu/about/covenant-community/ signatories / key-actions.html?scity_id=3822 (accessed on 1 December 2018). 
64. Hannover Key Actions. Available online: https://www.covenantofmayors.eu/about/covenant-community/ signatories / key-actions.html?scity_id=1610 (accessed on 1 December 2018).

65. Bree Key Actions. Available online: https://www.covenantofmayors.eu/about/covenant-community/ signatories/key-actions.html?scity_id=5231 (accessed on 1 December 2018).

66. Poole Key Actions. Available online: https://www.covenantofmayors.eu/about/covenant-community / signatories/key-actions.html?scity_id=6026 (accessed on 1 December 2018).

67. Málaga Key Actions. Available online: https://www.covenantofmayors.eu/about/covenant-community / signatories / key-actions.html?scity_id=1699 (accessed on 1 December 2018).

68. Paris Key Actions. Available online: https://www.covenantofmayors.eu/about/covenant-community/ signatories/key-actions.html?scity_id=1796 (accessed on 1 December 2018).

69. Lisboa Key Actions. Available online: https://www.covenantofmayors.eu/about/covenant-community / signatories/key-actions.html?scity_id=1872 (accessed on 1 December 2018).

70. Bremen Key Actions. Available online: https://www.covenantofmayors.eu/about/covenant-community/ signatories/key-actions.html?scity_id=1603 (accessed on 1 December 2018).

71. Fürstenfeldbruck Key Actions. Available online: https://www.covenantofmayors.eu/about/covenantcommunity/signatories/key-actions.html?scity_id=2167 (accessed on 1 December 2018).

72. Barcelona Key Actions. Available online: https://www.covenantofmayors.eu/about/covenant-community/ signatories / key-actions.html?scity_id=1950 (accessed on 1 December 2018).

73. Zagreb Key Actions. Available online: https://www.covenantofmayors.eu/about/covenant-community/ signatories / key-actions.html?scity_id=2019 (accessed on 1 December 2018).

74. Loures. Available online: https://www.covenantofmayors.eu/about/covenant-community/signatories / action-plan.html?scity_id=3118 (accessed on 1 December 2018).

75. Ringkøbing-Skjern Key Actions. Available online: https://www.covenantofmayors.eu/about/covenantcommunity/signatories/key-actions.html?scity_id=4302 (accessed on 1 December 2018).

76. Nijmegen Key Actions. Available online: https://www.covenantofmayors.eu/about/covenant-community/ signatories / key-actions.html?scity_id=2120 (accessed on 1 December 2018).

77. Eskilstuna. Available online: https://www.covenantofmayors.eu/about/covenant-community/signatories / action-plan.html?scity_id=2725 (accessed on 1 December 2018).

78. Lund. Available online: https://www.covenantofmayors.eu/about/covenant-community/signatories/keyactions.html?scity_id=2456 (accessed on 1 December 2018).

79. Ronchi Valsugana Key Actions. Available online: https://www.covenantofmayors.eu/about/covenantcommunity/signatories/key-actions.html?scity_id=6050 (accessed on 1 December 2018).

80. Mazzin Key Actions. Available online: https://www.covenantofmayors.eu/about/covenant-community/ signatories / key-actions.html?scity_id=6001 (accessed on 1 December 2018).

81. Rosà Key Actions. Available online: https://www.covenantofmayors.eu/about/covenant-community / signatories/key-actions.html?scity_id=5533 (accessed on 1 December 2018).

82. Roman. Available online: https://www.covenantofmayors.eu/about/covenant-community/signatories / action-plan.html?scity_id=8732 (accessed on 1 December 2018).

83. Este Key Actions. Available online: https://www.covenantofmayors.eu/about/covenant-community/ signatories / key-actions.html?scity_id=4901 (accessed on 1 December 2018).

84. Annicco Key Actions. Available online: https:/ / www.covenantofmayors.eu/about/covenant-community / signatories / key-actions.html?scity_id=5596 (accessed on 1 December 2018).

85. Banja Luka Key Actions. Available online: https://www.covenantofmayors.eu/about/covenantcommunity/signatories/key-actions.html?scity_id=2018 (accessed on 1 December 2018).

86. Bagnolo San Vito Key Actions. Available online: https://www.covenantofmayors.eu/about/covenantcommunity/signatories/key-actions.html?scity_id=3121 (accessed on 1 December 2018).

87. Liepāja Key Actions. Available online: https://www.covenantofmayors.eu/about/covenant-community/ signatories / key-actions.html?scity_id=6214 (accessed on 1 December 2018).

88. Baradili Key Actions. Available online: https://www.covenantofmayors.eu/about/covenant-community/ signatories/key-actions.html?scity_id=5534 (accessed on 1 December 2018).

89. City of Karlovac Key Actions. Available online: https://www.covenantofmayors.eu/about/covenantcommunity/signatories/key-actions.html?scity_id=2943 (accessed on 1 December 2018). 
90. Kozani Key Actions. Available online: https://www.covenantofmayors.eu/about/covenant-community / signatories / key-actions.html?scity_id=5540 (accessed on 1 December 2018).

91. Alken Key Actions. Available online: https://www.covenantofmayors.eu/about/covenant-community / signatories/key-actions.html?scity_id=5225 (accessed on 1 December 2018).

92. Gdynia Key Actions. Available online: https://www.covenantofmayors.eu/about/covenant-community/ signatories/key-actions.html?scity_id=3949 (accessed on 1 December 2018).

93. Castelnuovo Rangone Key Actions. Available online: https://www.covenantofmayors.eu/about/covenantcommunity/signatories/key-actions.html?scity_id=1828 (accessed on 1 December 2018).

94. Göteborg Key Actions. Available online: https://www.covenantofmayors.eu/about/covenant-community/ signatories/key-actions.html?scity_id=1884 (accessed on 1 December 2018).

95. Helsinki Key Actions. Available online: https:/ /www.covenantofmayors.eu/about/covenant-community / signatories/key-actions.html?scity_id=1765 (accessed on 1 December 2018).

96. Winkelomheide Key Actions. Available online: https://www.covenantofmayors.eu/about/covenantcommunity/signatories/key-actions.html?scity_id=7909 (accessed on 1 December 2018).

97. Ravenna Key Actions. Available online: https://www.covenantofmayors.eu/about/covenant-community/ signatories / key-actions.html?scity_id=1839 (accessed on 1 December 2018).

98. Stockholm. Available online: https://www.covenantofmayors.eu/about/covenant-community/ signatories / key-actions.html?scity_id=1888 (accessed on 1 December 2018).

99. Jönköping. Available online: https://www.covenantofmayors.eu/about/covenant-community/signatories / action-plan.html?scity_id=2447 (accessed on 1 December 2018).

100. Västerås Key Actions. Available online: https://www.covenantofmayors.eu/about/covenant-community/ signatories / key-actions.html?scity_id=6427 (accessed on 1 December 2018).

101. Milan Key Actions. Available online: https://www.covenantofmayors.eu/about/covenant-community/ signatories/key-actions.html?scity_id=1834 (accessed on 1 December 2018).

102. Aeroe. Available online: https://www.covenantofmayors.eu/about/covenant-community/signatories/ action-plan.html?scity_id=6640 (accessed on 1 December 2018).

103. Kristianstad Key Actions. Available online: https://www.covenantofmayors.eu/about/covenantcommunity/signatories/key-actions.html?scity_id=2495 (accessed on 1 December 2018).

104. Vittorio Veneto Key Actions. Available online: https://www.covenantofmayors.eu/about/covenantcommunity/signatories/key-actions.html?scity_id=6534 (accessed on 1 December 2018).

105. Ringsted Key Actions. Available online: https://www.covenantofmayors.eu/about/covenant-community/ signatories / key-actions.html?scity_id=2594 (accessed on 1 December 2018).

106. Växjö Key Actions. Available online: https://www.covenantofmayors.eu/about/covenant-community/ signatories/key-actions.html?scity_id=1889 (accessed on 1 December 2018).

107. Aachen Key Actions. Available online: https://www.covenantofmayors.eu/about/covenant-community / signatories/key-actions.html?scity_id=1601 (accessed on 1 December 2018).

108. Finspång Key Actions. Available online: https://www.covenantofmayors.eu/about/covenant-community / signatories / key-actions.html?scity_id=2548 (accessed on 1 December 2018).

109. Judenburg Key Actions. Available online: https://www.covenantofmayors.eu/about/covenantcommunity/signatories/key-actions.html?scity_id=4681 (accessed on 1 December 2018).

110. Bielsko-Biala Key Actions. Available online: https://www.covenantofmayors.eu/about/covenantcommunity/signatories/key-actions.html?scity_id=1865 (accessed on 1 December 2018).

111. Rijeka Key Actions. Available online: https://www.covenantofmayors.eu/about/covenant-community/ signatories/key-actions.html?scity_id=1815 (accessed on 1 December 2018).

112. Riga. Available online: https://www.covenantofmayors.eu/about/covenant-community/signatories/ action-plan.html?scity_id=1851 (accessed on 1 December 2018).

113. Lerum. Available online: https:/ / www.covenantofmayors.eu/about/covenant-community/signatories / action-plan.html?scity_id=7303 (accessed on 1 December 2018).

114. Lakatamia Key Actions. Available online: https://www.covenantofmayors.eu/about/covenantcommunity/signatories/key-actions.html?scity_id=6195 (accessed on 1 December 2018).

115. Seixal Key Actions. Available online: https://www.covenantofmayors.eu/about/covenant-community/ signatories / key-actions.html?scity_id=3801 (accessed on 1 December 2018). 
116. Bilbao Key Actions. Available online: https://www.covenantofmayors.eu/about/covenant-community / signatories / key-actions.html?scity_id=2909 (accessed on 1 December 2018).

117. Voznesensk Key Actions. Available online: https://www.covenantofmayors.eu/about/covenantcommunity/signatories/key-actions.html?scity_id=1900 (accessed on 1 December 2018).

118. Neumarkt in der Oberpfalz Key Actions. Available online: https://www.covenantofmayors.eu/about/ covenant-community/signatories/key-actions.html?scity_id=1617 (accessed on 1 December 2018).

119. Bertoldi, P.; Cayuela, D.B.; Monni, S.; de Raveschoot, R.P. How to Develop A Sustainable Energy Action Plan (SEAP)_Guidebook; Publication Office of the European Union: Luxembourg, 2010; p. 120.

120. Bertoldi, P.; Rivas, S.; Melica, G.; Palermo, V.; Dallemand, J.F. Guidebook "How to Develop A Sustainable Energy and Climate Action Plan (SECAP)": Part 1-The SECAP Process, Step by Step Towards Low Carbon and Climate Resilient Cities by 2030; EUR 29412; Publications Office of the European Union: Luxembourg, 2018.

121. Bertoldi, P.; Iancu, A.; Kona, A.; Suvi, M.; Muntean, M.; Lah, O.; Rivas, S. Guidebook “How to Develop A Sustainable Energy and Climate Action Plan (SECAP)": PART 2-Baseline Emission Inventory (BEI) and Risk and Vulnerability Assessment (RVA); EUR 29412; Publications Office of the European Union: Luxembourg, 2018.

122. Bertoldi, P.; Kona, A.; Palermo, V.; Zangheri, P.; Serrenho, T.; Rivas, S.; Labanca, N.; Kilkis, S.; Lah, O.; Glancy, R.; et al. Guidebook "How to Develop A Sustainable Energy and Climate Action Plan (SECAP)": PART 3-Policies, Key Actions, Good Practices for Mitigation and Adaptation to Climate Change and Financing SECAP(s); EUR 29412; Publications Office of the European Union: Luxembourg, 2018.

(C) 2019 by the authors. Licensee MDPI, Basel, Switzerland. This article is an open access article distributed under the terms and conditions of the Creative Commons Attribution (CC BY) license (http://creativecommons.org/licenses/by/4.0/). 